\title{
THE
}

\section{Atmospheric mercury over the NE Pacific during spring 2002: Gradients, residence time, upper troposphere lower stratosphere loss, and long-range transport}

\author{
L. F. Radke \\ H. R. Friedli \\ Brian G. Heikes \\ University of Rhode Island, bheikes@uri.edu
}

Follow this and additional works at: https://digitalcommons.uri.edu/gsofacpubs

Terms of Use

All rights reserved under copyright.

\section{Citation/Publisher Attribution}

Radke, L. F., H. R. Friedli, and B. G. Heikes (2007), Atmospheric mercury over the NE Pacific during spring 2002: Gradients, residence time, upper troposphere lower stratosphere loss, and long-range transport, $J$. Geophys. Res., 112, D19305, doi: 10.1029/2005JD005828.

Available at: https://doi.org/10.1029/2005JD005828

This Article is brought to you for free and open access by the Graduate School of Oceanography at DigitalCommons@URI. It has been accepted for inclusion in Graduate School of Oceanography Faculty Publications by an authorized administrator of DigitalCommons@URI. For more information, please contact digitalcommons-group@uri.edu. 


\title{
Atmospheric mercury over the NE Pacific during spring 2002: Gradients, residence time, upper troposphere lower stratosphere loss, and long-range transport
}

\author{
L. F. Radke, ${ }^{1,2}$ H. R. Friedli, ${ }^{2}$ and B. G. Heikes ${ }^{3}$ \\ Received 2 February 2005; revised 3 April 2007; accepted 23 May 2007; published 11 October 2007.
}

[1] Gaseous elemental mercury (GEM) was measured over the North Pacific and coastal California, Oregon and Washington in spring 2002 during the Intercontinental Transport and Chemical Transformation Experiment-2002 (ITCT2K2). Observations were made from the NOAA WP3 on 11 flights which spanned an altitude range of $0-8 \mathrm{~km}$ and latitudes between 35 and $55^{\circ} \mathrm{N}$. GEM was determined using a Tekran 2537A mercury instrument modified for airborne use to collect and analyze samples every 2.5 min under variable ambient temperature and pressure conditions. GEM concentrations were in general at the low end of previous measurements made over continents and in fresh continental outflow over the ocean. They showed (1) a significant vertical gradient in GEM between the lower sample altitudes and the upper altitudes, with median concentrations decreasing from 1.2 to $0.5 \mathrm{ng} \mathrm{m}^{-3}$; (2) GEM was depleted in upper troposphere lower stratospheric air and indicated this region is a sink for GEM; (3) GEM concentrations were $\sim 1 / 2$ at the surface to $\sim 1 / 4$ at midaltitudes of those observed immediately downwind of Asia during ACE-Asia, however; (4) highest GEM concentrations $\left(\sim 4 \mathrm{ng} \mathrm{m}^{-3}\right)$ were found in plume layers at concentrations comparable to those observed off the Asian coast in ACE-Asia; and (5) the observed variance in GEM suggested a lifetime on the order of 100 days, which was shorter than the previously accepted nominal lifetime of 1 year.

Citation: Radke, L. F., H. R. Friedli, and B. G. Heikes (2007), Atmospheric mercury over the NE Pacific during spring 2002: Gradients, residence time, upper troposphere lower stratosphere loss, and long-range transport, J. Geophys. Res., 112, D19305, doi:10.1029/2005JD005828.

\section{Introduction}

[2] Mercury, $\mathrm{Hg}$, is the only significant metallic atmospheric vapor and is typically present in air as gaseous elemental mercury, GEM, with a typical concentration between 1 to $2 \mathrm{ng} \mathrm{m}^{-3}$. GEM concentrations are usually reported in nanograms per standard cubic meter where standard temperature and pressure are $0^{\circ} \mathrm{C}$ and $1013.25 \mathrm{hPa}$, respectively. GEM has an oxidation state of zero and accounts for $98 \%$ of the tropospheric mercury burden. Particulate mercury $(\mathrm{pHg})$ and gaseous ionic or reactive mercury (RGM) comprise the bulk of the remaining $2 \%$. The residual atmospheric mercury is composed of the more highly toxic organic $\mathrm{Hg}$ forms like methylmercury. Regardless of form, mercury is a global-scale pollutant.

[3] GEM is released into the atmosphere from a multitude of sources, for example, fugitive emissions from industrial processes, coal combustion, waste incineration, biomass

\footnotetext{
${ }^{1}$ Airborne Research Consultants, Seattle, Washington, USA.

${ }^{2}$ Advanced Study Program, National Center for Atmospheric Research, Boulder, Colorado, USA.

${ }^{3}$ Graduate School of Oceanography, University of Rhode Island, Narragansett, Rhode Island, USA.

Copyright 2007 by the American Geophysical Union. 0148-0227/07/2005JD005828
}

fires, and volcanism. GEM is oxidized to RGM by hydroxyl, halogen, and nitrogen trioxide radicals and to a lesser extent by ozone [e.g., Pal and Ariya, 2004]. $\mathrm{Hg}$ in its more oxidized forms ( $\mathrm{Hg}^{\mathrm{II}}$, e.g., $\mathrm{HgO}, \mathrm{HgSO}_{4}, \mathrm{HgCl}_{2}$ ) can be further converted into $\mathrm{pHg}$. These compounds are thought to be relatively short-lived as the expected RGM to particle lifetime is $\sim 1$ day and particle lifetimes are of order 10 days [Fitzgerald et al., 1991; Hall, 1995; Schroeder and Munthe, 1998; Bergan and Rodhe, 2001; Nriagu and Becker, 2003].

[4] Elemental and oxidized mercury can be biologically and chemically converted in soils, fresh waters, oceans, and sediments to more highly reactive compounds and to the very toxic organic forms such as methylmercury. The organic forms of $\mathrm{Hg}$ are strongly "bioaccumulated" and concentrated up the food chain [Schroeder et al., 1991; Pilson, 1998], with occasionally disastrous results to human populations [Takizawa, 1979].

[5] Mercury tends to be released back into the air after deposition on Earth's surfaces and mercury's fluxes between environmental compartments are bidirectional [Mason et al., 1994; Richardson, 2001; Friedli et al., 2003a, 2003b]. Deposited mercury is revolatized by biological methylation, chemical reduction, photolysis and physical processes such as wildfire [Friedli et al., 2001]. Also, it remains unclear whether the global ocean is a net 
source or a net sink for atmospheric GEM, but the fluxes between atmosphere and ocean are significant [Fitzgerald, 1986; Temme et al., 2003; Mason and Sheu, 2002; Mason et al., 2001, 2002; Rasmussen, 1994; Pilson, 1998].

[6] Previous observations of mercury in the troposphere and the interpretation of its transport and atmospheric chemistry have lead others to conclude the lifetime of GEM is $~ 1$ year [e.g., Mason et al., 1994; Bergan and Rodhe, 2001] with estimates ranging from 0.5 to 2 years. This lifetime is under challenge. Recent measurements of ambient GEM in the Arctic [Lindberg et al., 2002a], ACE Asia, and forest fires [Lindberg et al., 2002b; Friedli et al., 2004] have suggested GEM is more variable than a 1-year lifetime would predict. Laboratory kinetic studies [e.g., Pal and Ariya, 2004] which considered halogen and $\mathrm{NO}_{3}$ radical chemistry suggest the GEM lifetime should be much shorter, on the order of a few months, depending upon the assumed atmospheric level of hydroxyl, halogen, or nitrogen trioxide radicals. Hedgecock and Pirrone [2004] considered GEM oxidation by $\mathrm{Br}, \mathrm{O}_{3}$, and $\mathrm{OH}$ and calculated boundary layer residence times as low as 10 days. When only oxidation by $\mathrm{OH}$ and $\mathrm{O}_{3}$ were considered, they estimated a GEM lifetime of 133 days. Selin et al. [2007] using the GEOS-CHEM system estimate a GEM global mean annual lifetime significantly shorter than 1 year and were only able to achieve an 8-month lifetime using a model parameter set selected to maximize GEM lifetime. These studies indicated GEM may have a much more dynamic character and call into question the details of current global atmospheric mercury budgets based upon a 1 year GEM lifetime [e.g., Lamborg et al., 2002a].

[7] There are only a handful of observations above the boundary layer with which to evaluate $\mathrm{Hg}$ budgets and chemical-transport theory. Tropospheric GEM observations are presented here from the Intercontinental Transport and Chemical Transformation Experiment-2002 (ITCT2K2). They were made aboard the NOAA WP-3 aircraft flown over the eastern North Pacific and along the west coast of the United States in spring 2002. ITCT2K2 was designed to examine the background composition of air before it had been modified by fresh North American emissions and to examine the long-range transport of pollutants from other continents. Observations were made on 11 flights, which spanned an altitude range of $0-8 \mathrm{~km}$ and latitudes between 35 and $55^{\circ} \mathrm{N}$. The flights went as far south as Los Angeles and as far north as the Northwest tip of Washington and traversed $\sim 50,000 \mathrm{~km}$. Airborne in situ GEM samples were analyzed using a modified Tekran 2573A mercury analyzer. Below, the modifications and testing of the instrument are described first. The ITCT2K2 GEM composition of air coming ashore to North America is presented next and the GEM data are then contrasted with previous observations, in particular with those made off the Asian-Pacific coast in spring 2000 as part of the Asian Pacific Regional Aerosol Characterization Experiment, ACE-Asia [Friedli et al., 2004] and those from Mt Batchelor, OR [Weiss-Penzias et al., 2003, 2006].

\section{Methods}

[8] GEM was measured with a Tekran 2537A mercury vapor analyzer (Tekran Inc., Toronto, Canada) modified to eliminate the known pressure dependence of the standard instrument. Figure 1 shows a schematic of the sampling and measurement arrangement used on the aircraft and is described in detail below. Sample air was brought into the aircraft via a rear-facing $1 / 4$ inch Teflon tube inlet and plumbed to the instrument. It then passed through a $47 \mathrm{~mm}, 0.2 \mu \mathrm{m}$ Teflon filter in a Teflon housing to remove particles. Sample air then passed through one of two gold cartridges where gaseous mercury was collected. The processed air was discharged into a dump line and vented overboard. The sample airflow rate from inlet to dump was regulated by the Tekran's internal pump. This pump was programmed to draw $1.50 \mathrm{slpm}$ (standard liters per minute, $\mathrm{T}=273.15 \mathrm{~K}, \mathrm{P}=1013.25 \mathrm{hPa}$ ). Sample air was replaced by mercury-free zero air for instrument startup and instrument background checks. The zero air was generated by drawing ambient air through a Resisorb activated carbon canister (Tekran Inc.). The Tekran internal pump was used to draw ambient sample air and to generate zero air. Ultrahigh-purity Ar (99.999\%, Scott Specialty Gases) was used as the carrier gas for gold cartridge desorption and the desorbed mercury was quantified by cold vapor atomic fluorescence spectroscopy. The Ar pressure in the desorbing gold cartridge and in the fluorescence cell was maintained at $1026 \mathrm{hPa}(1.013 \mathrm{~atm})$ using a MKS Series 640 electronic pressure controller, which was plumbed to the outlet of the fluorescence cell. Detector Ar pressure control was a significant modification and the rationale and testing of this modification are explained more fully below.

\subsection{Tekran 2537A Operation}

[9] The Tekran 2537A instrument concentrated mercury from a metered air sample flow by amalgamating it on a gold cartridge. There are two gold cartridges ("A" and "B") in parallel flow paths. These were cycled between a collection state and an analysis state to permit continuous sampling every $150 \mathrm{~s}$. In state 1, sample air passed through the cartridge, GEM was collected and the spent air exhausted. In state 2, an isolated Ar carrier stream was passed through the cartridge to displace sample air. After a set period of Ar flow, the cartridge was rapidly heated desorbing the previously collected elemental mercury into the Ar carrier. The thermally desorbed mercury was passed through a fluorescence cell and quantified by cold vapor atomic fluorescence spectroscopy. The instrumental detection limit was about $0.1 \mathrm{ng} \mathrm{m}^{-3}$ (GEM concentrations are reported in nanograms per standard cubic meter where standard temperature and pressure are $0^{\circ} \mathrm{C}$ and $1013.25 \mathrm{hPa}$, respectively).

[10] The output from the Tekran 2537A instrument was designated as total gaseous mercury (TGM), which includes GEM and the unknown fraction of reactive gaseous mercury (RGM) not scavenged on internal instrument surfaces. RGM is generally present in the atmosphere as a small fraction of GEM [Lindberg and Stratton, 1998]. There are exceptions as Lindberg et al. [2002a, 2002b] observed elevated RGM fractions during Arctic mercury depletion events. A $0.2 \mu \mathrm{m}$ Teflon filter is placed ahead of the mercury analyzer to remove particulate mercury and potential aerosol contamination from the sample. Thus the GEM measurements were effectively composed of gaseous elemental mercury alone and referred to as GEM. We have 


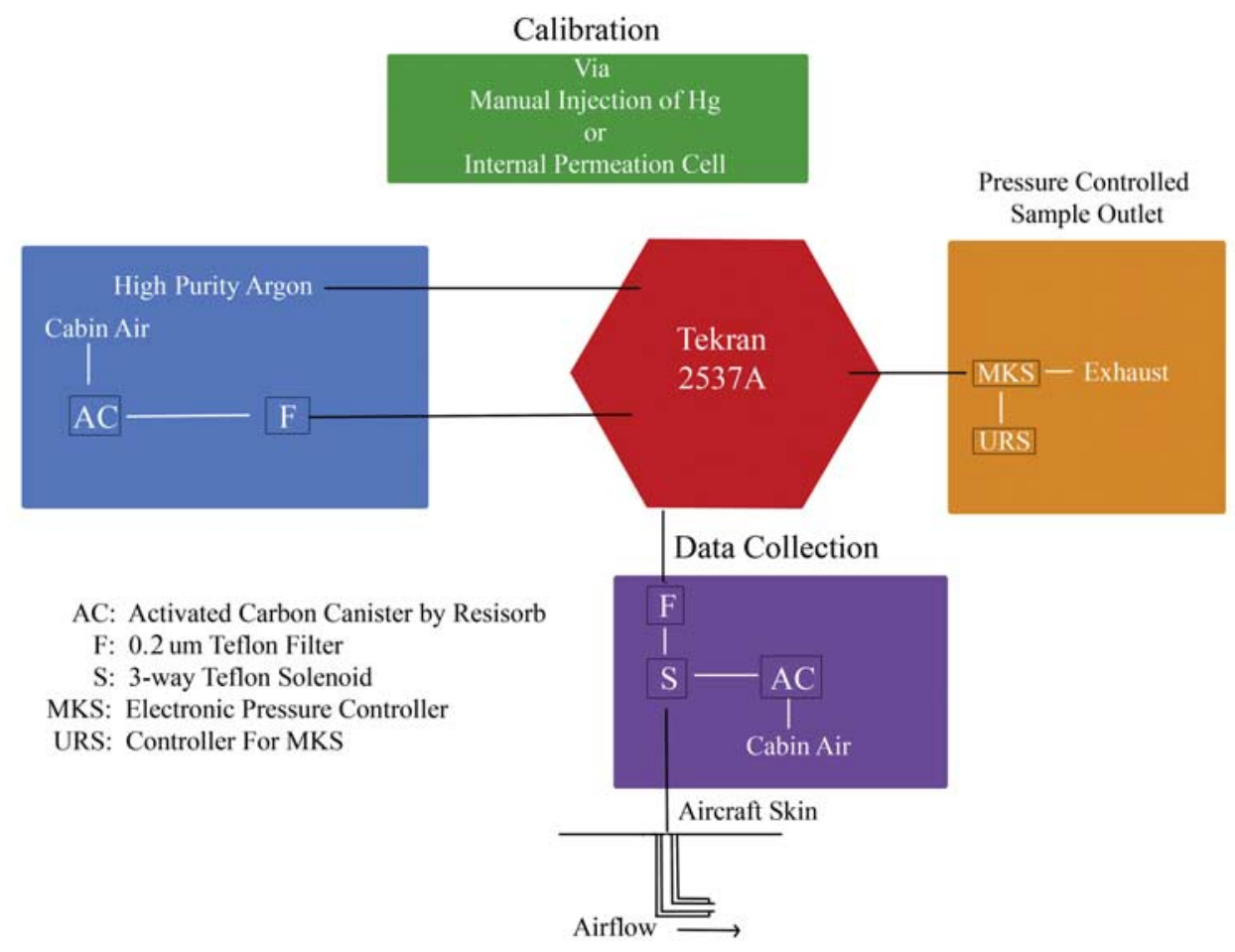

Figure 1. Schematic of the mercury sampling system as installed on the NOAA P-3 aircraft. Bored out bulkhead fittings are used to seal the cabin from the ambient air at the aircraft skin and at the tip of the inlet probe. Note the modification and use of a pressure controller on the exhaust side of the Tekran 2537A fluorescence cell to keep the Ar gas carrier pressure at a constant $1026 \mathrm{hPa}$.

assumed the RGM fraction was small, but if not RGM would constitute an unquantifed positive artifact in our GEM data.

[11] The instrument was calibrated premission and postmission using an internal GEM permeation cell and the calibration was verified by manual injection of known amounts of GEM supplied from a Tekran 2505 Gaseous Mercury Calibrator (Tekran Inc., Toronto, Canada). The permeation cell and manual injections agreed to within $1 \%$ and $2 \%$ for the A and B cartridges, respectively. Calibration factors before the experiment were $6166 \pm 113$ counts/ picogram for cartridge A $(\mathrm{n}=13), 6085 \pm 179$ counts/ picogram $(n=13)$ for $B$ and were stable. In the field, permeation cell calibrations and manual calibrations were not possible because of logistical constraints. Hence throughout the field phase of the experiment, the instrument used the last permeation cell calibration as the default, $\mathrm{A}=6351 \mathrm{cts} / \mathrm{pg}$ and $\mathrm{B}=6319 \mathrm{cts} / \mathrm{pg}$. At the end of the field experiment, the instrument was recalibrated in the laboratory, the calibration factors were, $\mathrm{A}=5044 \pm 56 \mathrm{cts} / \mathrm{pg}$ $(\mathrm{n}=8)$ and $\mathrm{B}=5256 \pm 70 \mathrm{cts} / \mathrm{pg}(\mathrm{n}=8)$, indicating a $20.6 \%$ and $16.8 \%$ decrease in response for the $\mathrm{A}$ and $\mathrm{B}$ cartridges, respectively, over the course of the field deployment. The data have been corrected for this drift by assuming the decrease in response was linear over instrument operation time. In support of this, we noted the absence of a temporal trend in our oceanic boundary layer data throughout the deployment, which remained near a constant value of $1.2 \mathrm{ng} \mathrm{m}^{-3}$ and significant jumps in oceanic boundary layer GEM were not observed between flights. Instrument background measurements before and after each flight were always small and constant.

[12] Instrument blanks were attempted in flight using "Zero Air" generated in situ by passing the sample air stream through a commercially prepared activated carbon canister (Resisorb, Tekran Inc.). Meaningful blanks were not obtained until it was discovered that a fraction of the mercury that was adsorbed on the activated carbon at low altitude desorbed at high altitudes. The data reported here are uncorrected for a gold cartridge-derived fluorescence background.

\subsection{Mercury Measurement Issues Unique to Aircraft Operation}

[13] Previous work has shown the Tekran instrument responds to variations in pressure. This could come about through pressure effects on air sample volume, gold cartridge collection efficiency, carrier flow, and detector response. The sample airflow rate is controlled using a mass flowmeter and a circuit which regulates the sample pump's speed to maintain a constant mass flow rate $(1.50 \mathrm{slpm} ; \mathrm{T}=273.15 \mathrm{~K}, \mathrm{P}=1013.25 \mathrm{hPa})$. At higher altitudes (lower air pressures) the pump was found to be undersized and unable to maintain constant mass flow. Fortunately, a constant mass flow rate is not required as the mass flow rate from the meter is monitored and 


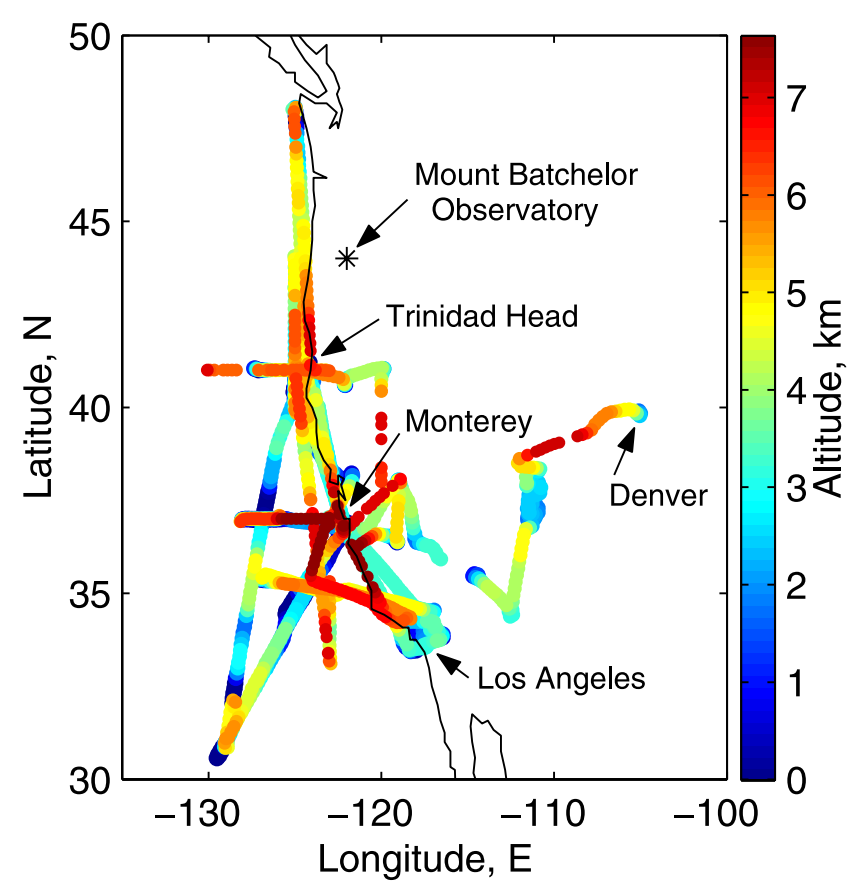

Figure 2. ITCT2K2 flight tracks on which mercury observations were made. Altitude of sample is indicated by color.

integrated over the time of a sample to derive the total sample volume in standard liters (STP). It is this total sample volume, which is used to calculate GEM in $\mathrm{ng} \mathrm{m}^{-3}$.

[14] Ebinghaus and Slemr [2000] demonstrated that the Tekran 2537A's gold tube traps quantitatively collected GEM (100\% efficiency) to their test limit of $500 \mathrm{hPa}$ ( $\sim 5.5 \mathrm{~km}$ altitude). Further, the Gormley and Kennedy [1949] equations indicate diffusional wall loss in a tube is independent of pressure under laminar constant mass flow. On the basis of these works, we assumed the diffusive collection of GEM on the collecting gold spheres is $100 \%$ up to our highest sample altitudes $(\sim 8 \mathrm{~km}$ or $\sim 400 \mathrm{hPa})$. This was verified in the laboratory and the results are presented below.

[15] The Tekran's detector system has been shown to be sensitive to operating pressure [Ebinghaus and Slemr, 2000; Friedli et al., 2003b]. These investigators determined and applied an empirical pressure-correction algorithm to their airborne observations. The pressure dependence of the Tekran's cell was determined by us for pressures from 800 to $1026 \mathrm{hPa}$. The pressure response was linear and $0.118 \%$ per $\mathrm{hPa}(\mathrm{A})$ and $0.114 \%$ per $\mathrm{hPa}(\mathrm{B})$. These values were very similar to those reported by the above authors. To avoid the need for this pressure correction, an electronic pressure controller (MKS Series 640) was installed at the exit of the cold vapor atomic fluorescence detection cell to maintain a constant detection system operating pressure in the cell and in the gold cartridge during the thermal desorption process. A set point pressure of $1026 \pm 2 \mathrm{hPa}$ was selected to ensure the cell pressure always exceeded ambient pressure during the field experiment. The controller was tuned to avoid oscillations triggered by surges in $\mathrm{Ar}$ flow, which resulted from the Tekran's internal flow switching sequences.
[16] Premission the MKS pressure control system and the assumption about the gold tube's sampling efficiency were evaluated. A Tedlar bag containing a known concentration of GEM was prepared. The bag was plumbed to the Tekran inlet through a Teflon throttle valve, which allowed the inlet pressure to be varied. The indicated $\mathrm{Hg}$ concentration remained constant as the inlet pressure was reduced stepwise over the range expected to be experienced aboard the WP-3.

[17] Postmission the Tekran's pressure dependence was reevaluated in the laboratory over a wider pressure range from 830 to $300 \mathrm{hPa}, 100 \mathrm{hPa}$ below the operational range experienced during the field experiment. Manual injections into sample flows at 600 and $300 \mathrm{hPa}$ resulted in responses of 5864 and 6002 counts per picogram, indicating that the response was relatively unaffected $(\sim 2 \%)$ even at these lowest pressures.

[18] As will be presented below, the ITCT2K2 GEM altitude distributions showed, contrary to expectation, a significant decrease in concentration with altitude above 3 to $4 \mathrm{~km}$. We searched for possible experimental or instrumental artifacts that could have contributed to decreasing GEM concentrations with increasing altitude. Plumbing leaks were one possibility. In the field, the manufacture's leak check procedures were followed and no leaks were found. Postmission, a second set of checks were performed as part of our research into the collection efficiency of the gold cartridges and detector pressure response. Again, no leaks were found.

[19] One additional note about data reduction is needed. At about 6000 to $7000 \mathrm{~m}$ altitude and above, the output of the Tekran instrument reported " 0 " as the amount of GEM collected fell below the instruments internal criteria for "good data." This resulted from two factors. First, the sampled air total volume fell below a prescribed minimum sample volume, as the pump had insufficient capacity at higher altitudes. Second, the small sample volume coupled with low mercury concentrations at these altitudes failed to deliver a sufficient quantity of mercury during desorption to generate a signal above a preset threshold value relative to baseline that the instrument could detect and integrate. Under either condition the instrument reports " 0 " GEM. This resulted in an effective high-altitude detection limit of $0.2 \mathrm{ng} \mathrm{m}^{-3}$. These " 0 " samples were removed during postmission data reduction. The removal of these " 0 " values introduced a potential positive bias in our observations at highest altitudes.

\section{Results}

[20] Approximately 1600 observations with quantifiable GEM concentrations were made on 11 WP-3 flights during ITCT2K2. The flight tracks are shown in Figure 2 for the 9 sorties based from Monterey, CA. Another 60 samples fell below practical detection limits, $0.1 \mathrm{ng} \mathrm{m}^{-3}$ from the surface to $\sim 5 \mathrm{~km}$ and $0.2 \mathrm{ng} \mathrm{m}^{-3}$ above $\sim 5 \mathrm{~km}$. Each sample was collected over $150 \mathrm{~s}$, with a sample's start and stop times defining the GEM time base used to present the data. Most other instruments had faster response times and reported data at much shorter intervals, e.g., $\mathrm{CO}, \mathrm{H}_{2} \mathrm{O}$, or $\mathrm{O}_{3}$. The faster measured constituents have been averaged over the GEM sample start-stop time and merged to the 

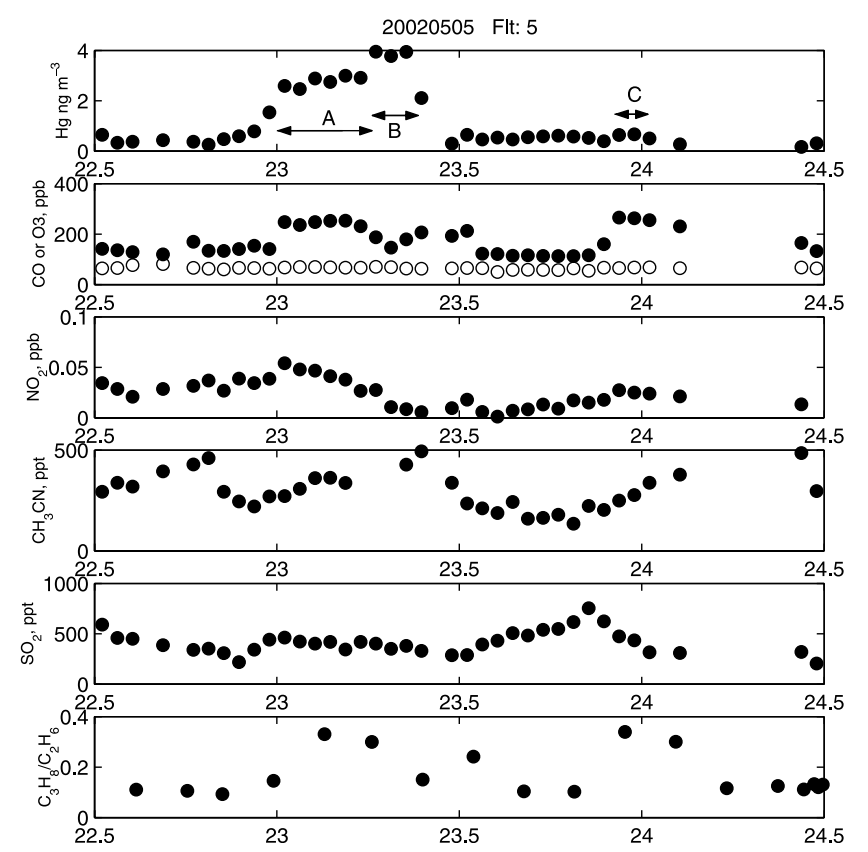

Figure 3. Timelines for GEM, $\mathrm{CO}$ (solid circle), $\mathrm{O}_{3}$ (open circle), $\mathrm{NO}_{2}$, acetonitrile, $\mathrm{SO}_{2}$, and the ratio of propane to ethane on 5 May 2002. All data lie between 4 and $8 \mathrm{~km}$. This flight encountered three elevated GEM plumes (3, 4 and $0.7 \mathrm{ng} \mathrm{m}^{-3}$ ) at $23.0-23.25,23.25-23.4$, and $23.9-$ 24.0 UT. Each GEM plume is associated with a variable mix of copollutants. $\mathrm{CO}, \mathrm{O}_{3}, \mathrm{SO}_{2}$, and acetonitrile have been averaged (merged) to the GEM time base. Propane/ethane is from whole air samples and is plotted on an independent time base-midpoint of whole air sample collection time.

GEM time base for display and analysis. However, the whole-air-sampler used for hydrocarbon measurements, e.g., ethyne, ethane, and propane, had a variable sample length and irregular collection interval and its data were not merged to the GEM time base. Instead these data are displayed using their own time base with fast properties merged to that time base.

[21] The data presentation is organized to highlight three case studies: a long-range transported (LRT) plume(s), the sampling of the Los Angeles Basin (LAB) air, and the sampling of an upper tropospheric-lower stratospheric (UTLS) impacted air mass. Figures 3-5 highlight the LRT plume encountered on 5 May 2002. Figures 6-8 depict the air composition over the Los Angeles Basin. Figures 9-11 show the influence of UTLS air on GEM. Figure 12 shows a summary of GEM measured in ITCT2K2 and is compared with data from ACE-Asia. Figure 13 shows, for completeness, the GEM vertical distribution measured for the other 8 flights.

[22] $\mathrm{CO}, \mathrm{O}_{3}$, ethyne, ethane and propane are shown for all three case studies. Acetonitrile, $\mathrm{SO}_{2}$, and $\mathrm{NO}_{2}$ observations are shown for the LRT and LAB pollution cases. CO was chosen as a general long-lived pollution tracer and because the GEM-CO ratio was used previously to identify Asian plumes reaching North America [e.g., Jaffe et al., 2005]. $\mathrm{O}_{3}$ served as both a long-lived pollution tracer as well as an indicator of stratospheric influence. $\mathrm{NO}_{2}, \mathrm{SO}_{2}$, ethyne, ethane and propane were selected as representative pollution tracers of moderate lifetime (1-10 days). In addition, both ethyne to $\mathrm{CO}$ and propane to ethane ratios have been used as qualitative indicators of air mass processing.

[23] The propane to ethane ratio was used as a qualitative measure of the extent an air parcel has been processed by atmospheric chemistry, (e.g., $\mathrm{OH}$ ), and by mixing since having left a hydrocarbon source region. The ethyne to $\mathrm{CO}$ ratio gave a similar measure and was more indicative of air mass processing since leaving combustion source regions. The propane to ethane ratio is presented here and its use in this capacity has been discussed previously [Gregory et al., 1997; McKeen et al., 1996]. Ratios greater than 0.3 indicated relatively little air mass processing has occurred (fresh), whereas, values less than 0.1 indicated some of the more highly processed air masses (well aged). In the Los Angeles Basin case study (13 May, Figures 6 and 7), the propane to ethane ratio was as high as 1.3 near the surface and by $4 \mathrm{~km}$ altitude had dropped to below 0.1 ; in keeping with a fresh to well processed air gradient. In the Asian plume case study (5 May, Figure 4), the ratio only exceeded 0.2 within the high $\mathrm{CO}$ plume region at $5-7 \mathrm{~km}$. In general, below $2.5 \mathrm{~km}$ the ratio was quite often less than 0.1 and associated with air containing lower ethyne, ethane, and $\mathrm{CO}$ mixing ratios. This highly processed air exhibited some of the lowest measured GEM encountered at these lower altitudes.

\subsection{Transport Meteorology}

[24] Parrish et al. [2004] and Nowak et al. [2004] have summarized the general meteorology during ITCT2K2. Briefly, flight days and flight plans were selected to sample several air mass characteristics, which included, in part, rapid transit across the Pacific, minimal offshore influence of North American emissions, and generally cloud free conditions. This selected for meteorologically stable conditions and against air masses associated with recent strong vertical mixing. Hence potential temperature profiles for nearly all of the flights indicated a very stable atmosphere aloft and a resultant lack of vertical mixing. Further, within the study region there was a strong subsidence inversion capping the marine boundary layer. This can be seen in GEM, relative humidity and potential temperature profiles and was most evident on the 2,15 and 17 May flights. GEM is plotted on Figure 13 and this strong inversion is noted by the apparent step change in GEM above $\sim 0.7 \mathrm{~km}$ to abruptly lower values.

[25] During the project, only 5 and 10 May exhibited large $\mathrm{CO}$ plumes $(\mathrm{CO}>100 \mathrm{ppb}$ over background) indicating lofted Asian air masses with rapid long-range transport to the coast of California. The 5 May plume (presented as the 10 May example) was complicated by mixing with stratospherically influenced air [Cooper et al., 2004], and was possibly further influenced by North American emissions as its parcel trajectory (not shown) showed it to have traveled at low altitudes along the coast.

\subsection{GEM Distributions During ITCT2K2}

[26] The vertical distribution of GEM for individual flights is shown in Figures 4, 7, and 13. Typically, GEM was found to be relatively constant or to decrease slightly from the surface to some intermediate altitude, nominally 


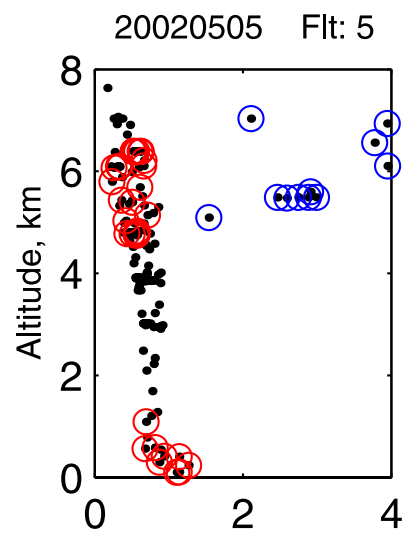

$\mathrm{Hg}, \mathrm{ng} \mathrm{m}^{-3}$

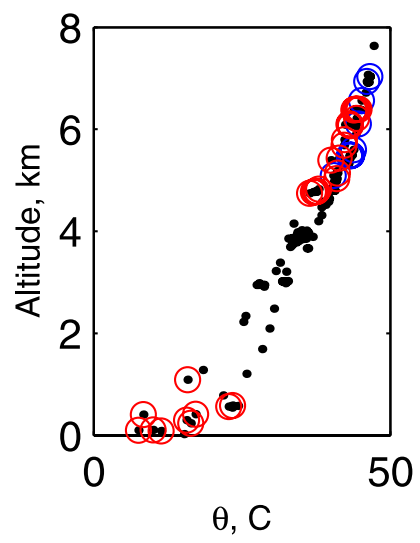

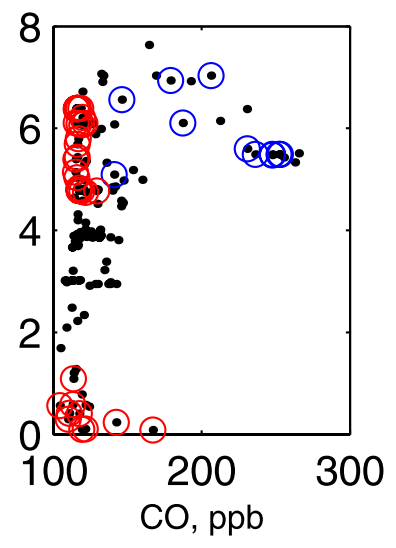
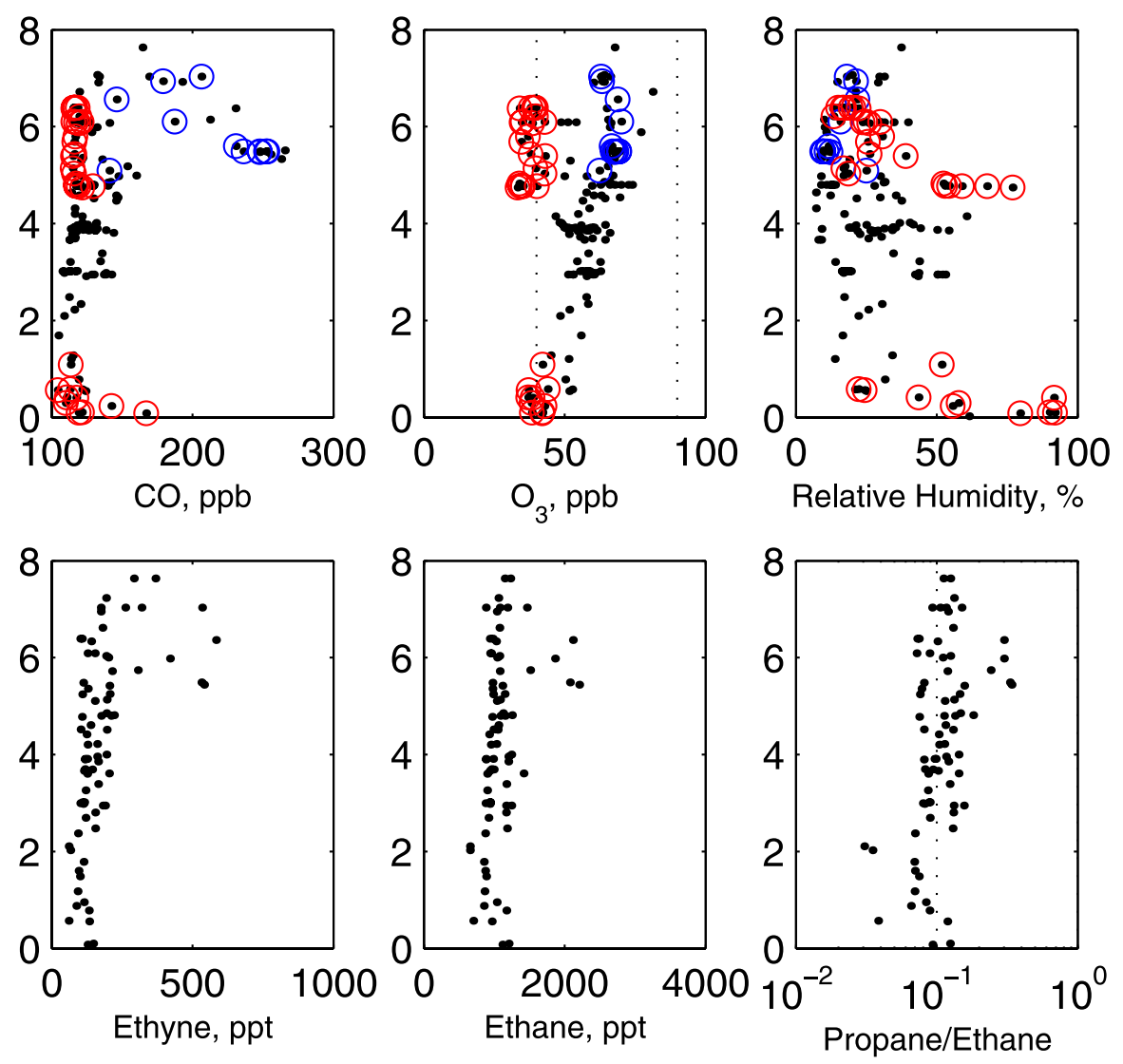

Figure 4. Composite vertical distributions of GEM, $\mathrm{CO}, \mathrm{O}_{3}$, relative humidity, potential temperature, ethyne, ethane and the propane-ethane ratio for the flight on 5 May 2002. Red circles show data when $\mathrm{O}_{3}<45 \mathrm{ppb}$. Blue circles indicate data when $\mathrm{GEM}>1.4 \mathrm{ng} \mathrm{m}^{-3} . \mathrm{CO}, \mathrm{O}_{3}$, relative humidity and potential temperature have been averaged (merged) to the GEM time base. Ethyne, ethane and propane/ethane ratio are not circled as they have a different time base, but high ratios correspond with higher CO and GEM.

$3-4 \mathrm{~km}$, above which it distinctly decreased with altitude. We have called this intermediate altitude the GEM mixed depth and it is listed for each flight in Table 1. A composite vertical distribution of GEM for all 11 ITCT2K2 flights is shown in Figure 12. Thereon the median, 25th and 75th percentiles are plotted for $1 \mathrm{~km}$ layers altitude. Note the pronounced decrease in GEM from the lower altitudes to the upper altitudes. The GEM decrease with altitude was unexpected and is commented upon more fully in the discussion section.

[27] Table 2 lists the mean GEM, CO, $\mathrm{O}_{3}$, and $\mathrm{H}_{2} \mathrm{O}$ values for contiguous-in-time observations from each flight for the lowest altitudes sampled over the ocean. Mean latitude, longitude, and a land reference point are listed, too. The data were selected to have ambient pressures less than $985 \mathrm{hPa}$, which corresponds to a maximum sample altitude of $250 \mathrm{~m}$. This thin vertical interval was chosen because a deeper $0-1 \mathrm{~km}$ layer often selected air mass samples from both above and below the MBL top. The number of samples for each contiguous set of observations is listed; there were as few as one and as many as 32 (when the aircraft devoted approximately $1 \mathrm{hr}$ to sampling off Trinidad Head, CA, 2 May) individual data points per mean value given. Also depending upon the flight, there were as few as one and as many as four legs at low altitude. The low-level legs were further sorted by distance from the coast, more than $100 \mathrm{~km}$ or within $100 \mathrm{~km}$ west of the coastline. While on first inspection there was a suggestion that near coastal observations were higher than those further out to sea, the differences in the means were not statistically significant. Nor was there a significant trend with latitude. However, there was a small, but significant secular trend in the data with flight index or time. To ensure a temporal bias in flight location did not drive the trend, the time series of observations located near Trinidad Head, CA, and at Monterey, CA, were separately examined. The Monterey data showed a modest, but significant trend with time, although, the Trinidad Head data did not. As mentioned in the methods section, the low-altitude data were used as a check on the assumed linear calibration correction and to rule out flight-to-flight changes in instrument sensitivity.

[28] A comparison of the ITCT2K2 0-250 m data with other Pacific data is given in Table 3. The ITCT2K2 data were lower on average and exhibited a lower range of values than previous work, although our mean falls within the range of these studies. Table 3 also shows a comparison of a subset of the ITCT2K2 data with elevated 


\section{NATIONAL OCEANIC ATMOSPHERIC ADMINISTRATION Backward trajectory ending at 23 UTC 05 May 02 FNL Meteorological Data}

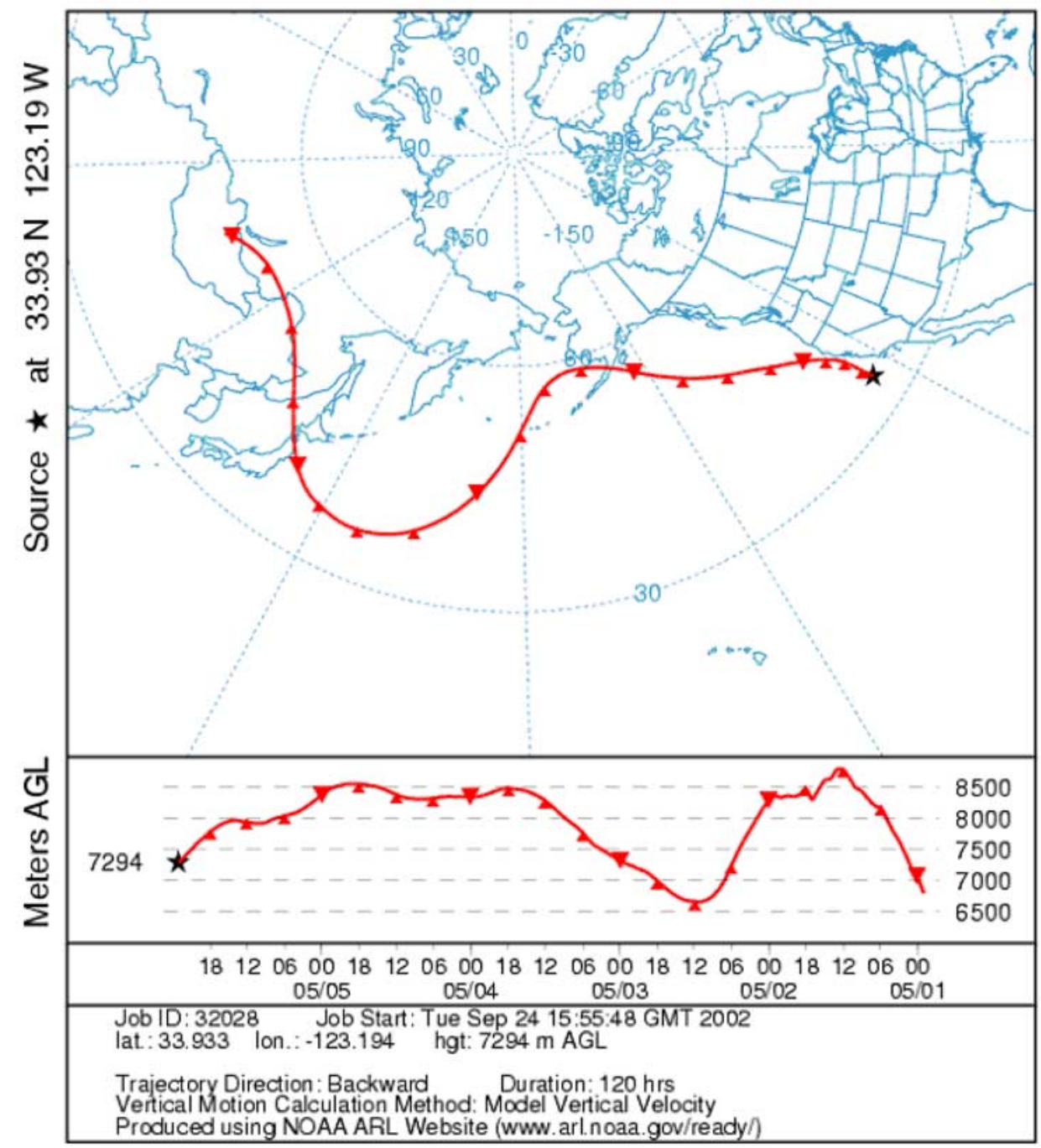

Figure 5. NOAA back trajectory for an air parcel containing high GEM sampled at $7294 \mathrm{~m}$ off the California coast and showing a 5-day transit time crossing the Aleutians, Japan and Manchuria.

mountain sites, Cheeka Peak, WA, and Mt. Batchelor Observatory, OR. The ITCT2K2 data for this comparison were selected to be north of $40^{\circ} \mathrm{N}$ and between 2.3 and $3.3 \mathrm{~km}$ so as to best compare with $\mathrm{MBO}$ latitude and altitude. Selected MBO data from 15 April to 27 May were chosen to provide a \pm 10 -day overlap with the ITCT2K2 sample period. The MBO data were from 2004 and 2005 as MBO was not operational in 2002. The ITCT2K2 GEM data were about $50 \%$ lower. Not listed are comparisons for $\mathrm{CO}, \mathrm{O}_{3}$, and water vapor, which showed the selected ITCT2K2 samples to be $50 \%$ lower in water vapor, $20 \%$ lower in $\mathrm{CO}$ and $30 \%$ higher in $\mathrm{O}_{3}$. This indicated the ITCT2K2 air masses to be less polluted and to have originated at higher, colder and drier altitudes. To match $\mathrm{MBO}$ values, required using ITCT2K2 observations from 0 to $2 \mathrm{~km}$ and from south of $35^{\circ} \mathrm{N}$.
[29] The altitude variation was the predominant feature in GEM distributions. To isolate that effect from other analyses, the data from all flights were sorted into $1 \mathrm{~km}$ layers or bins. GEM displayed a relatively constant background concentration in each layer and it was possible to visually identify GEM peaks or "plumes" larger than $0.15 \mathrm{ng} \mathrm{m}^{-3}$ above the local background. Similarly, CO, O3 and a suite of other chemicals were examined for deviations above background, which would indicate a "plume" event. The threshold for $\mathrm{O}_{3}$ and $\mathrm{CO}$ events was 5 and $10 \mathrm{ppb}$, respectively. Events having $\mathrm{O}_{3}, \mathrm{CO}$ and GEM positively correlated were interpreted as pollution transport events. There were 2 clear events on 29 April and 10 May where CO and GEM were positively correlated, but with $\mathrm{O}_{3}$ negatively correlated. It is our interpretation these samples corresponded with stratospheri- 


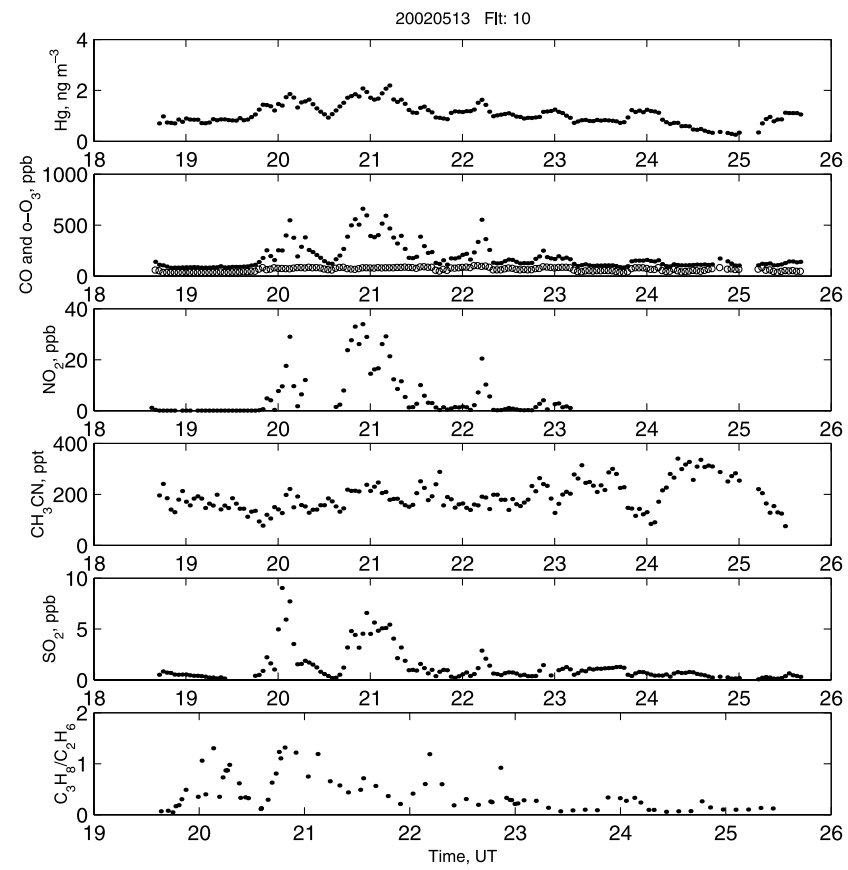

Figure 6. Same as Figure 3 but for the flight on 13 May 2002. This flight was primarily at low altitudes over the Los Angeles Basin. The period from 19.6 to 24.2 UT shows repetitive transects over the basin at different altitudes.

cally influenced air. Table 1 lists the flights by date and whether they exhibit CO-GEM plumes above four $\mathrm{km}(\mathrm{H})$ and below four $\mathrm{km}(\mathrm{L})$. While GEM and $\mathrm{CO}$ were positively correlated for the most part, it should also be noted that not all
GEM events have visually detectable higher CO nor did all $\mathrm{CO}$ events have visually detectable higher GEM.

\subsection{Asian Plume Case}

[30] The vertical and horizontal distributions of GEM were significantly altered by distant and local sources on a portion of only four flights, 5, 13, 17 and 19 May 2002. The flight on 13 May was the Los Angeles sortie and is presented below. The flight on 19 May was the transit flight back to Colorado and the large GEM values were encountered on the decent into Denver. The 17 May high GEM appears to have been in North American outflow. On 10 May plumes of other species were encountered but changes in GEM were small, on the order of $0.2-0.3 \mathrm{ng} \mathrm{m}^{-3}$, and were near stratospherically impacted air with GEM dips of -0.3 to $-0.4 \mathrm{ng} \mathrm{m}^{-3}$ associated with $50 \mathrm{ppv}$ spikes in $\mathrm{O}_{3}$. The 150 s GEM sample integration interval may have smeared the pollution and the UTLS air masses together during this portion of the flight. On 5 May, plumes were encountered at an altitude of 5-7 km and had GEM up to $4 \mathrm{ng} \mathrm{m}^{-3}$. This flight paralleled the coast extending from 33 to $44^{\circ} \mathrm{N}$ (Figure 2). The plume was located to the north with clean air to the south.

[31] During the 5 May 2002, flight three distinct plumes were encountered based upon CO and GEM. The selected parameters are shown as a function of time on Figure 3 for the plume period. Figure 4 shows vertical distributions of selected parameters for the entire flight. A backward air trajectory for the plume period is shown on Figure 5. Plume "A" is defined to extend from 23.0 to 23.25 UT on Figure 3 and has GEM concentrations of $2.5-3.0 \mathrm{ng} \mathrm{m}^{-3}$. Plume "B" extended from 23.25 to 23.35 UT and has the highest GEM at $4.0 \mathrm{ng} \mathrm{m}^{-3}$. Plume "C" was less distinct in its

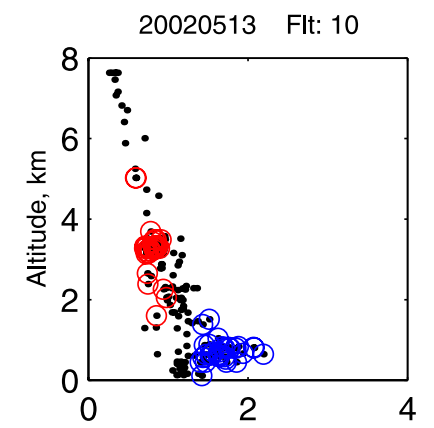

$\mathrm{Hg}, \mathrm{ng} \mathrm{m}^{-3}$
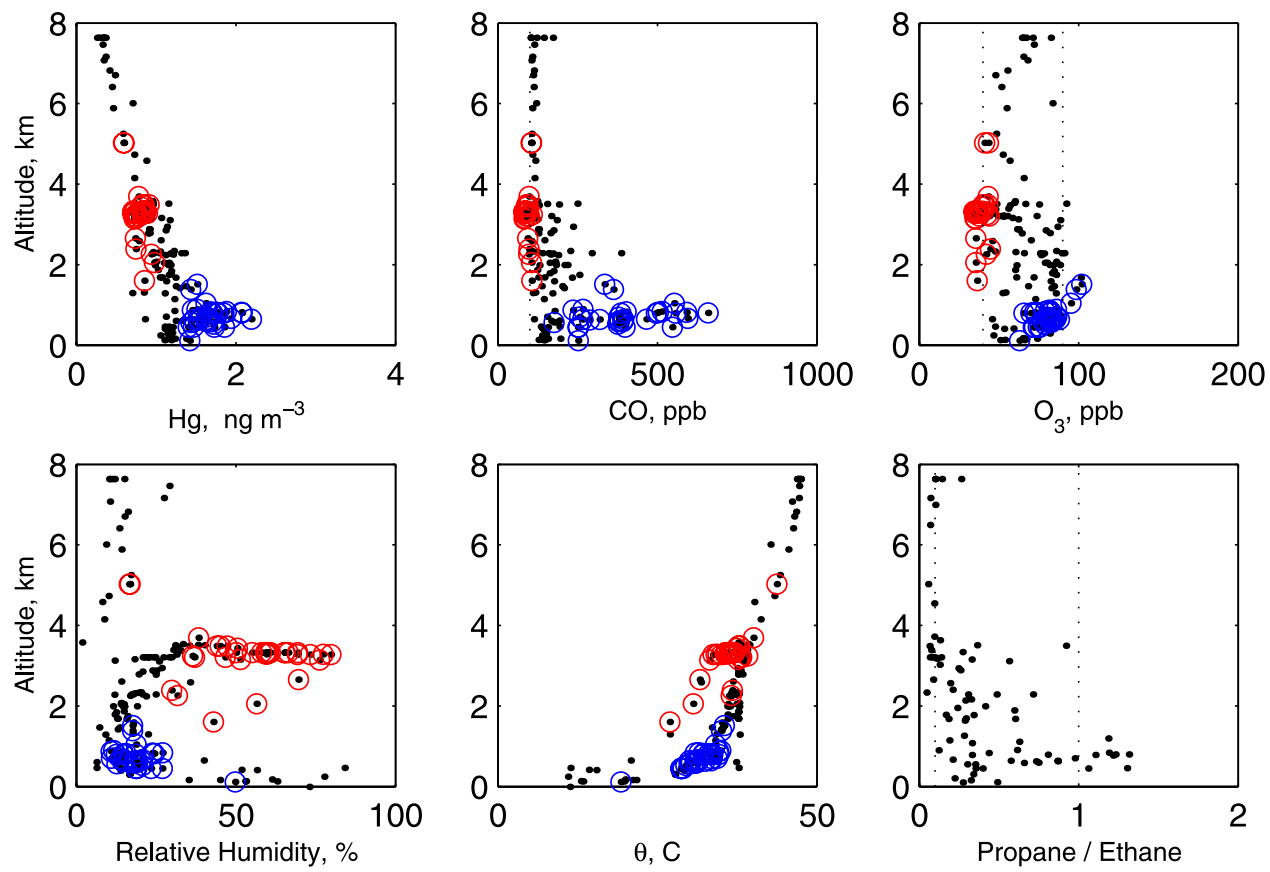

Figure 7. Same as Figure 4 but for the flight on 13 May 2002, sampling the Los Angeles Basin. Note in the potential temperature panel the sounding's transitions from neutral to stable conditions. The low $\mathrm{O}_{3}$ data come from the Monterey to Los Angeles transit and return. They show some of the lowest CO, GEM, and propane-ethane ratios encountered in ITCT2K2. 

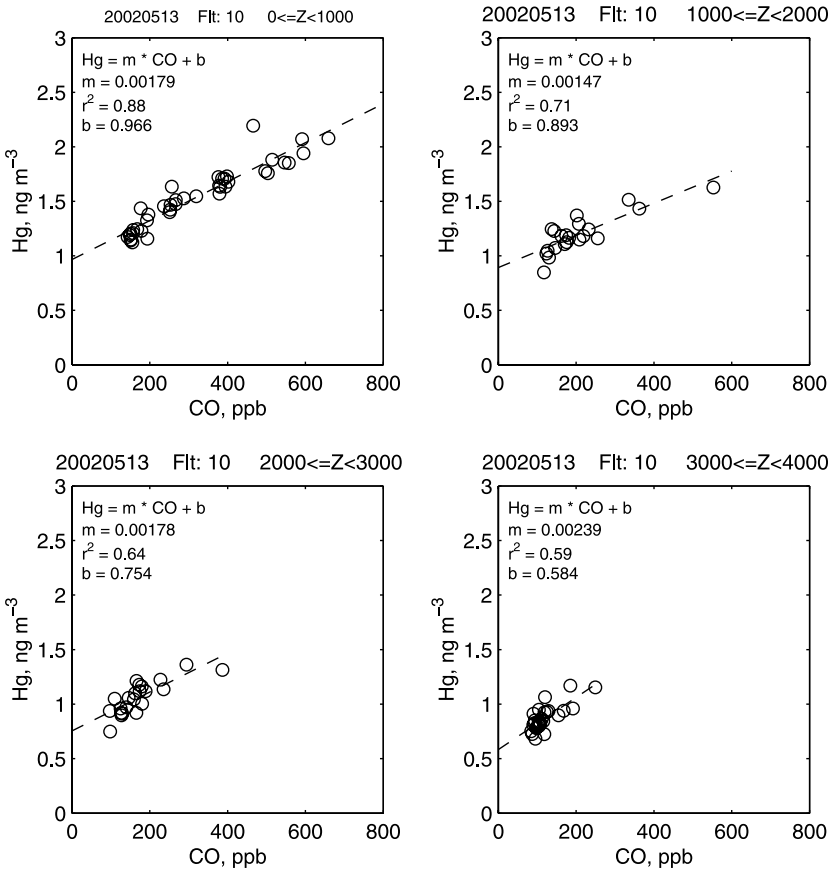

Figure 8. Correlations between $\mathrm{CO}$ and GEM at four altitude zones: $0-1,1-2,2-3$, and $3-4 \mathrm{~km}$, during 13 May 2002 over the Los Angeles Basin. The slope, intercept and regression coefficient are listed on each panel.
GEM concentration, extended from 23.9 to 24.05 UT and had GEM $<0.3 \mathrm{ng} \mathrm{m}^{-3}$ above background. CO mixing ratios in the $A, B$ and $C$ plumes were 125,100 and $150 \mathrm{ppb}$, respectively, above a background mixing ratio of $125 \mathrm{ppb}$. $\mathrm{O}_{3}$ was relatively constant at $75 \mathrm{ppb}$. It can be seen that (1) plumes $\mathrm{A}$ and $\mathrm{C}$ contained elevated $\mathrm{NO}_{2}$; (2) plumes $\mathrm{A}$, $\mathrm{B}$, and $\mathrm{C}$ contained elevated acetonitrile; (3) plumes $\mathrm{A}, \mathrm{B}, \mathrm{C}$ had elevated $\mathrm{SO}_{2}$ but the highest $\mathrm{SO}_{2}$ was just prior to plume C; and (4) plumes A and C had the "freshest" air, propane to ethane $\sim 0.35$, compared to $\mathrm{B}, \sim 0.25$.

[32] This illustrated the variability in GEM and other species composition in a LRT plume(s) event. The $\triangle$ GEM: $\triangle \mathrm{CO}$ ratios $\left(\mathrm{ng} \mathrm{\textrm {m } ^ { - 3 }} \mathrm{ppb}^{-1}\right.$ ) were $0.024,0.035$ and 0.002 in plumes $\mathrm{A}, \mathrm{B}$ and $\mathrm{C}$, respectively. Elevated ethyne $(\sim 500 \mathrm{ppt})$ and ethane $(\sim 2000 \mathrm{ppt})$ in the plume at altitude is shown on Figure 4.

[33] Figure 4 facilitates identification of background air with which to compare plume concentrations. Data when GEM is greater than $1.4 \mathrm{ng} \mathrm{m}^{-3}$ are circled in blue. Data when $\mathrm{O}_{3}$ was less than $45 \mathrm{ppb}$ are circled in red. The red circled points have the highest relative humilities, lowest $\mathrm{CO}$ and lowest GEM at the altitude of the plume. Separately, it was determined the lowest ethyne, ethane, and propaneethane ratio $(\sim 0.06)$ corresponded with the lowest $\mathrm{O}_{3}$ at plume altitude. This flight encountered some of the "cleanest" most processed air at its southern end as well as the Asian plume(s) to the north.

\section{Flt: 3}

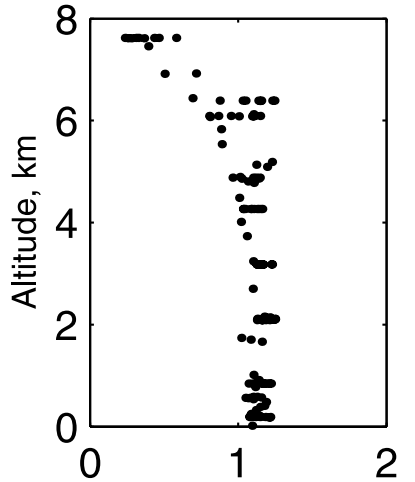

$\mathrm{Hg}, \mathrm{ng} \mathrm{m}^{-3}$

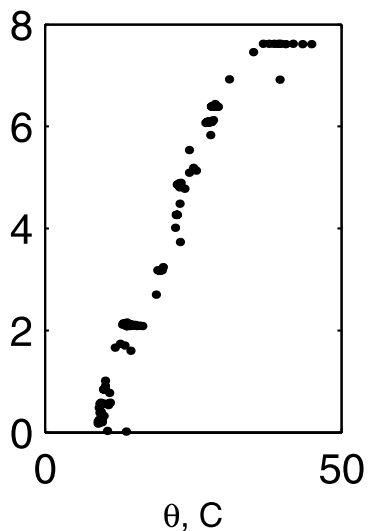

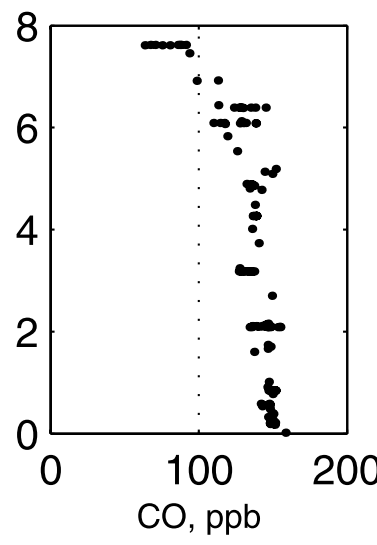
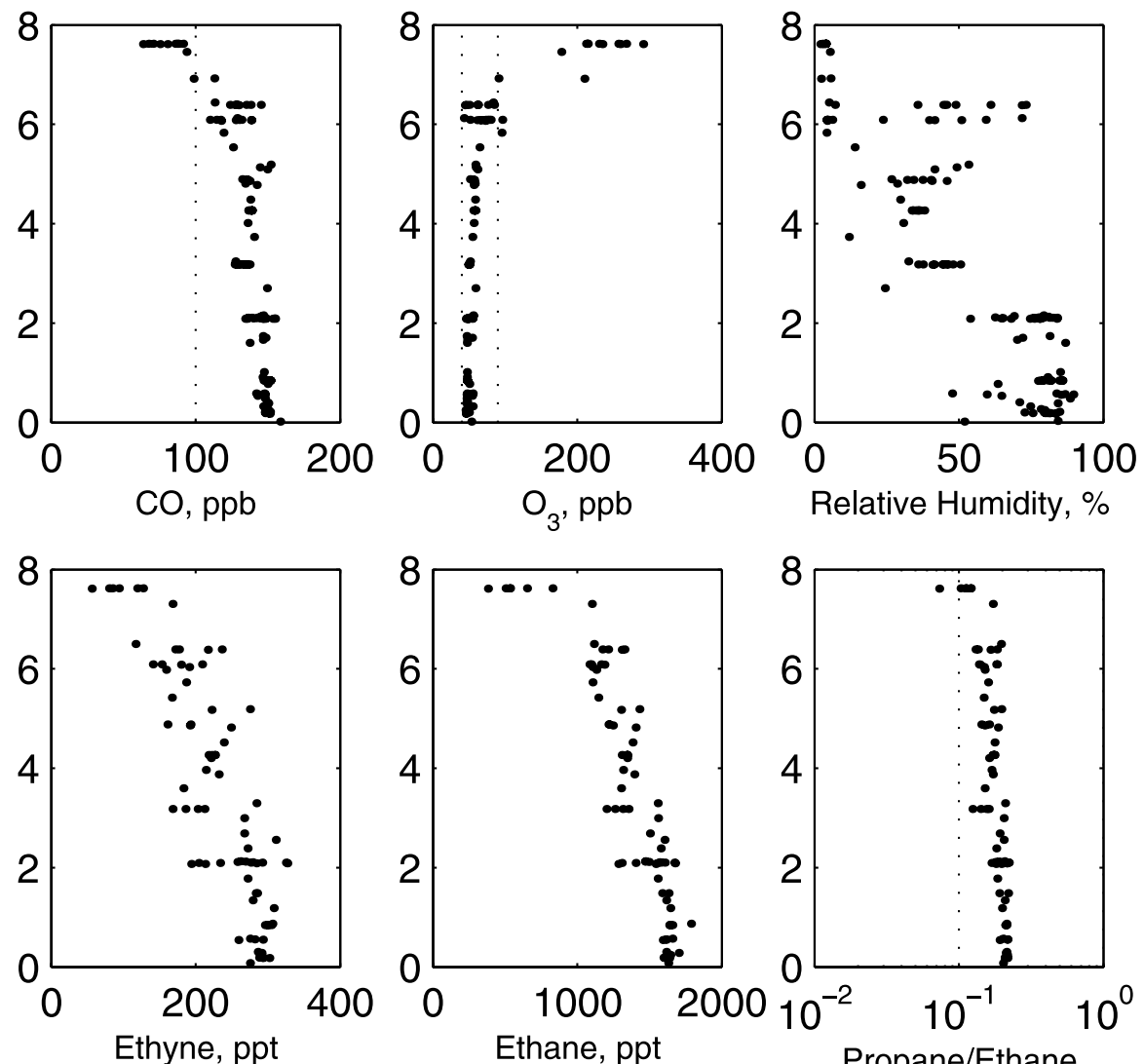

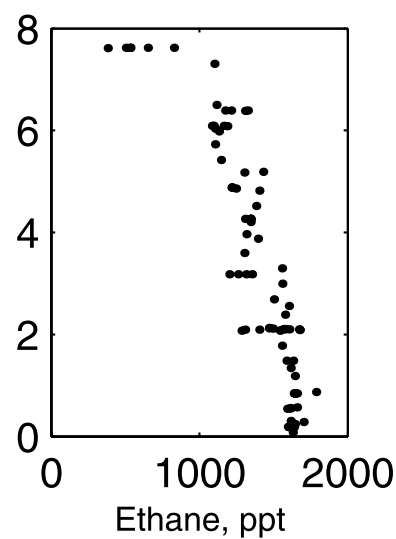

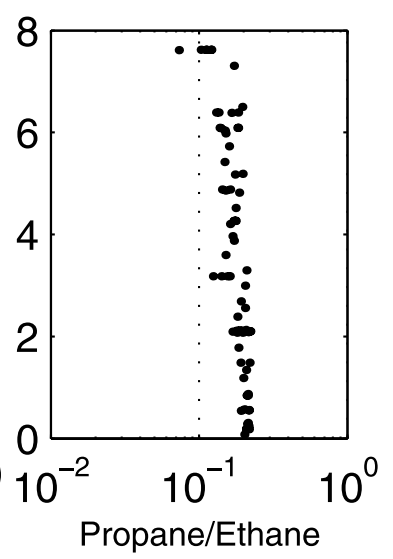

Figure 9. Same as Figure 4 but for the flight on 29 April 2002, while investigating a cutoff low. The high $\mathrm{O}_{3}$ and low values for other chemical components indicates sampling of stratospherically influenced air above $6 \mathrm{~km}$. 


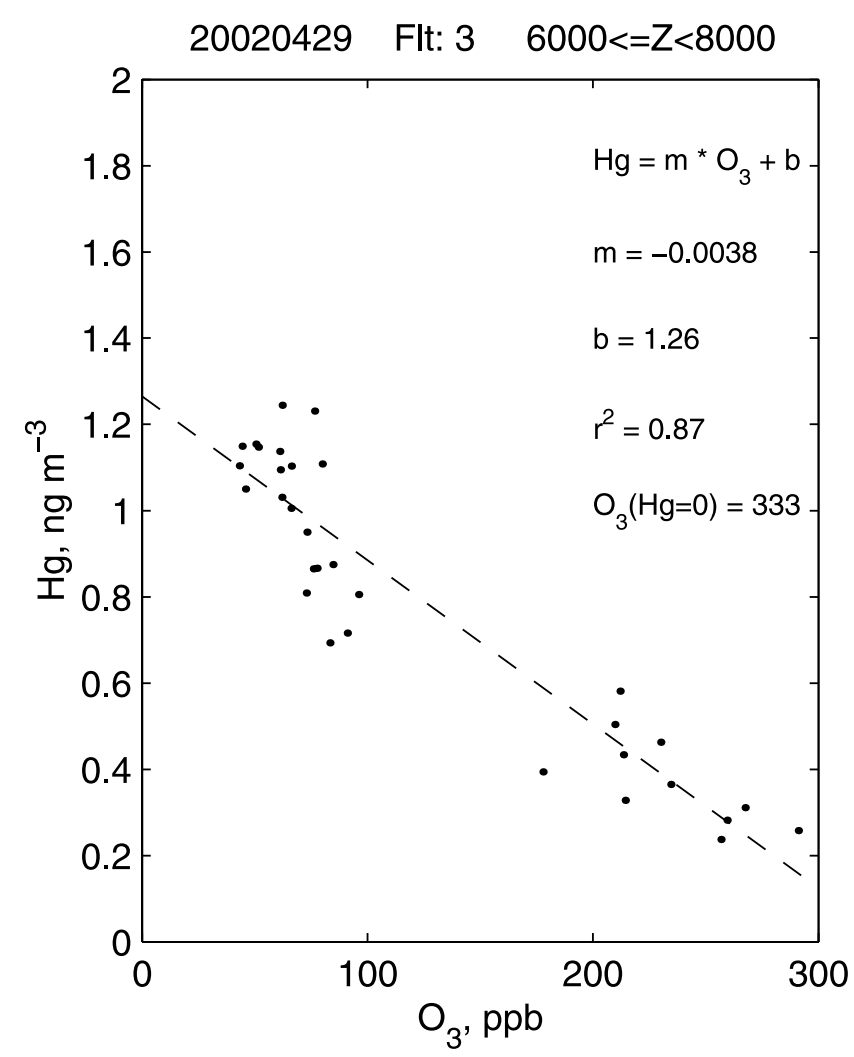

Figure 10. GEM and $\mathrm{O}_{3}$ correlation above $6 \mathrm{~km}$ in the stratospherically influenced air on 29 April 2002. The slope, intercept and regression coefficient are listed. Extrapolation of the line to $\mathrm{GEM}=0$ would yield an $\mathrm{O}_{3}$ value of $333 \mathrm{ppb}$.

[34] Backward trajectory analysis suggested plume A originated from near the marine boundary layer off the coast of China and reached the sampling site after $\sim 10$ days. The trajectory for plume $\mathrm{B}$ is shown in Figure 5 and indicates this air moved across the Pacific at about twice the speed of the lower one, and $\sim 5$ days before our observations, it passed over Mongolia at $>8000 \mathrm{~m}$. The source of the fast-moving plume was not known, but de Gouw et al. [2004] identified acetonitrile as one of the pollutants in these plumes, which suggested a biomass burning contribution and deep pyroconvection.

\subsection{Los Angeles Basin Case Study}

[35] The 13 May flight within the Los Angeles Basin showed a broadly distributed urban GEM source region. The entire flight concentration timeline for GEM, $\mathrm{CO}, \mathrm{O}_{3}$, $\mathrm{NO}_{2}$, acetonitrile, $\mathrm{SO}_{2}$ and propane-ethane ratio are shown in Figure 6. Vertical distributions of GEM, $\mathrm{CO}, \mathrm{O}_{3}$, relative humidity, potential temperature, and propane-ethane ratio are shown on Figure 7. Data points when GEM was greater than $1.4 \mathrm{ng} \mathrm{m}^{-3}$ are circled in blue. Data when $\mathrm{O}_{3}$ was less than $45 \mathrm{ppb}$ are circled in red. The depth of the urban boundary layer was $\sim 3.5 \mathrm{~km}$ as noted in $\mathrm{CO}$, relative humidity (rel-hum), and propane to ethane ratio. The highest GEM, $2.2 \mathrm{ng} \mathrm{m}^{-3}$, was confined to lower altitudes and appeared capped at the main inversion: sharp potential temperature increase at $1-1.5 \mathrm{~km}$. Highest $\mathrm{CO}$, propane to ethane ratio, $\mathrm{O}_{3}, \mathrm{NO}_{2}$, and $\mathrm{SO}_{2}$, were found at these lowest altitudes, too. There was a high correlation between primary pollutant species. This is illustrated for CO-GEM on Figure 8, which shows the correlation between these 2 species in the $0-1,1-2,2-3$ and 3-4 km layers over the Basin. The CO-GEM slope varied from 0.0015 to 0.0024 with an average value of $0.0018\left(\mathrm{ng} \mathrm{m}^{-3} \mathrm{ppb}^{-1}\right)$.

[36] The low $\mathrm{O}_{3}$ data $(<45 \mathrm{ppb})$ were principally located along the Monterey to Los Angeles transit line at $3.5 \mathrm{~km}$. This transit showed some of the highest relative humidity aloft, lowest CO and mixed propane-ethane ratios (19.5 to 20.5 UT on Figure 6) suggestive of air mass mixing along the coast.

\subsection{Stratospheric Influence Case Study}

[37] GEM was observed in stratospherically influenced air masses on 29 April 2002 and 10 May 2002. The 29 April case provided a clearer demonstration of stratospheric influence with $\mathrm{O}_{3}$ values approaching $300 \mathrm{ppb}$. Figure 9 shows vertical distributions of GEM, $\mathrm{CO}, \mathrm{O}_{3}$, relative humidity, potential temperature, and propane-ethane ratio. The UTLS air began at about $6 \mathrm{~km}$ and extended beyond the highest sample altitude $(8 \mathrm{~km})$. This was evident in potential temperature, relative humidity, GEM, CO, and most clearly in $\mathrm{O}_{3}$. Ethyne and ethane also showed a decrease with increasing $\mathrm{O}_{3}$ above $\sim 80$ ppbv.

[38] The anticorrelation between $\mathrm{O}_{3}$ and GEM is illustrated in Figure 10. The data were for the altitudes above $6 \mathrm{~km}$. The data showed a GEM to $\mathrm{O}_{3}$ slope of $-0.0038 \mathrm{ng} \mathrm{m}^{-3} \mathrm{ppb}^{-1}$. Extrapolation of the line to $0 \mathrm{GEM}$ yielded an $\mathrm{O}_{3}$ value of $333 \mathrm{ppb}$. There was also an anticorrelation between $\mathrm{CO}$ and $\mathrm{O}_{3}$ and which is not shown. In the UTLS air, there was a

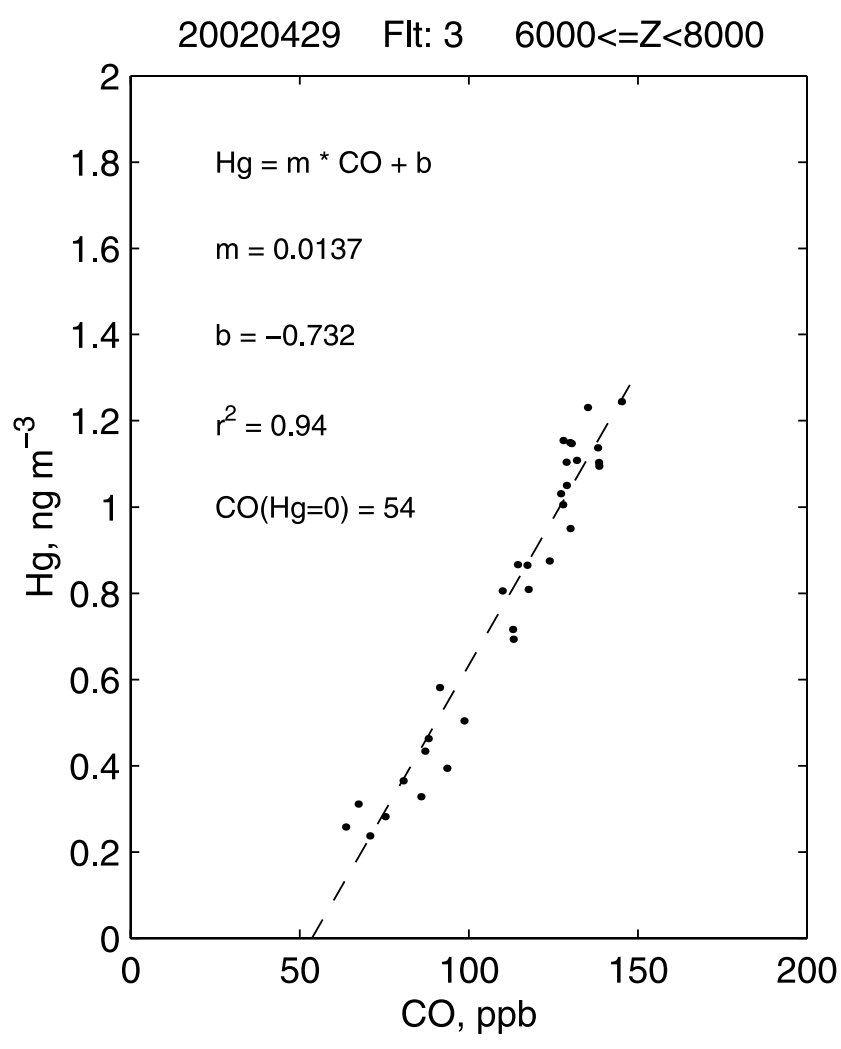

Figure 11. Same as Figure 10 except for GEM and CO. The extrapolation of the line to $\mathrm{GEM}=0$ yields a $\mathrm{CO}$ value of $54 \mathrm{ppb}$. 

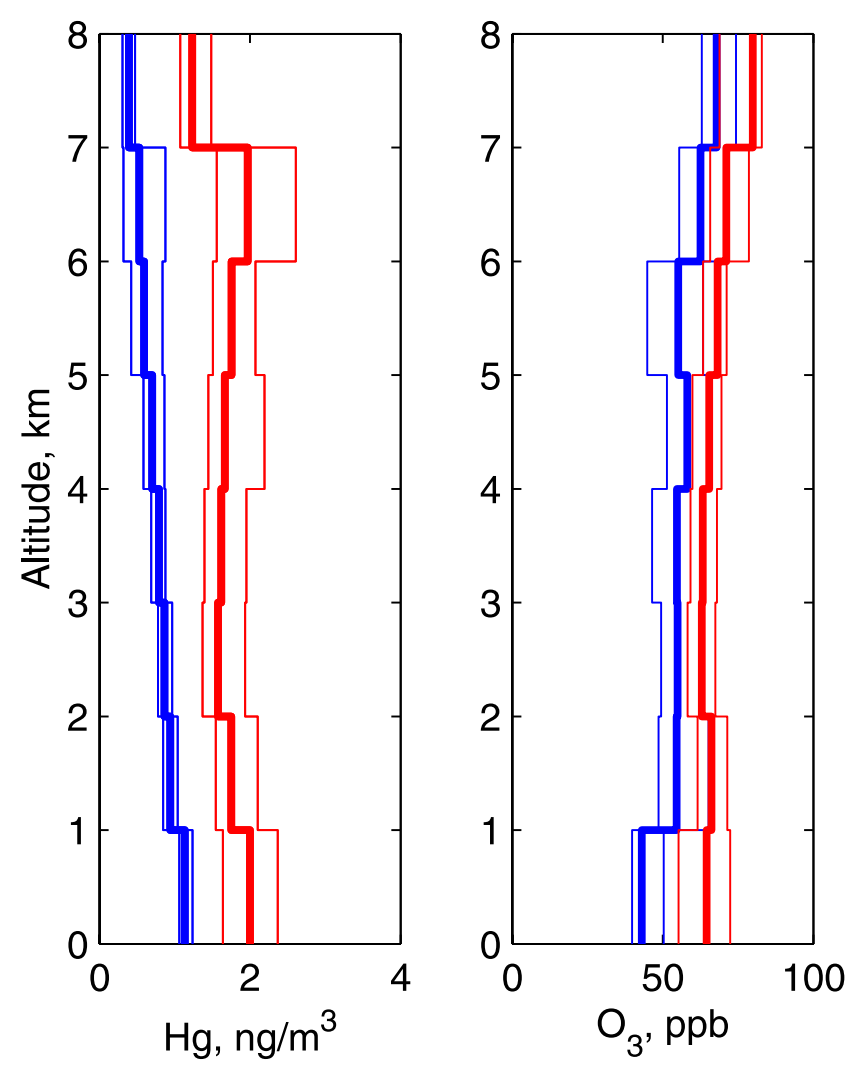

Figure 12. Distributions of (left) GEM and (right) O3, binned at $1 \mathrm{~km}$ intervals during ACE-Asia (red) from the Asian side of the Pacific and during ITCT2K2 (blue) on the California side. The thicker lines indicate median values, and the thin lines show 25th and 75th percentiles. O3 and GEM were significantly lower in ITCT2K2 on the downwind side of the Pacific. Also they were anticorrelated during ITCT2K2.

very strong correlation between GEM and CO. This is shown on Figure 11. The GEM-CO slope was $0.0137 \mathrm{ng}$ $\mathrm{m}^{-3} \mathrm{ppb}^{-1}$, which we propose was driven by the relative loss of each going into the stratosphere. Extrapolating to 0 GEM yielded a $\mathrm{CO}$ value of $54 \mathrm{ppb}$. We have also fit the $\mathrm{O}_{3}-\mathrm{CO}$ data for this period and the extrapolation of $\mathrm{CO}$ to 54 ppbv yielded an $\mathrm{O}_{3}$ value of $333 \mathrm{ppb}$, a value below tropospheric mixing ratios and in keeping with UTLS values. The 3 variables GEM-CO-O 3 yielded a self-consistent endmember for lower stratospheric air mixing with upper tropospheric air of $0-54-340$, respectively.

[39] Figure 9 also showed that at the base of the layer there appeared to be a convected layer with high relative humidity, CO, GEM, ethane and propane to ethane ratio but with lower $\mathrm{O}_{3}$. The vertical distribution of many species below the UTLS indicated this was one of the more vertically well-mixed sampling days. The flight on 24 April was similar in this regard (not shown). Both had nearly constant GEM with altitude, until UTLS encounter.

\section{Discussion}

[40] Four aspects of the ITCT2K2 GEM data set were notable in their implications to mercury in the atmosphere and the interpretation of its natural atmospheric cycles. First is the vertical gradient in GEM. Second is the GEM observations implying a 100-day residence time for GEM. Third, the apparent quantitative loss of GEM in the UTLS is a new finding of undetermined significance to GEM cycling and may afford a new tracer for UTLS air exchange. Fourth, the GEM-CO ratios in Asian plumes, in urban air, and the UTLS vary by well over an order of magnitude. Last, new GEM questions are posed.

\subsection{Vertical Gradients of GEM}

[41] Given the generally long residence times previously estimated for tropospheric GEM, it has been widely assumed that GEM would be vertically well mixed and that little or no gradient would be observed by aircraft soundings of the troposphere. Prior to our observations, the limited numbers of GEM soundings by instrumented aircraft flown above the PBL have yielded different results; GEM increasing with altitude, GEM decreasing with altitude and GEM constant with altitude.

[42] GEM and $\mathrm{O}_{3}$ soundings for ITCT2K2 and ACEASIA are plotted as 25th, 50th and 75th percentiles in Figure 12. The ITCT2K2 data show strong altitude dependence for both GEM and $\mathrm{O}_{3}$. ACE-Asia's data was different and exhibited a " $\mathrm{C}$ " shaped profile with altitude. The values at all altitudes were significantly greater in ACE-Asia than during ITCT2K2. The "C" profile suggested GEM sources at the surface and frontal or convective lofting of the boundary layer air to $4-7 \mathrm{~km}$. The low concentrations at $7-8 \mathrm{~km}$ suggested an absence of pollutant mixing to this height or mixing with GEM depleted air. It should be emphasized that in ACE-Asia the objective was to sample pollution mixed into the middle to upper troposphere and the higher GEM concentrations at these altitudes reflected this bias. Banic et al. [2003] observed nearly constant to slightly decreasing GEM with altitude (surface to $7 \mathrm{~km}$ ) over Canada in all seasons. R. H. Ebinghaus (personal communication, 2006) has recently also observed GEM to substantially decrease in the UTLS. Below we present a case study documenting a marked decrease in GEM under stratospherically influenced conditions.

[43] The earliest GEM vertical sounding observations of Abramovsky et al. [1977] revealed a strong negative gradient of more than an order of magnitude from the surface to $4 \mathrm{~km}$. Kvietkus [2003] also found a negative gradient with concentrations falling $60 \%$ from the surface to $4 \mathrm{~km}$. Ebinghaus and Slemr [2000] obtained two vertical soundings. One of these soundings showed no significant gradient and the second showed a strong negative gradient from the surface to $2.3 \mathrm{~km}$ and no GEM gradient from $2.3 \mathrm{~km}$ to $3.7 \mathrm{~km}$. R. H. Ebinghaus (personal communication, 2006) also reported a negative gradient in the lowest $0.2 \mathrm{~km}$ from a coastal tower. In an extensive series of soundings over southeastern Canada, Ontario, and the Canadian Arctic, Banic et al. [2003] found the concentration of GEM to be largely invariant from the surface to $7 \mathrm{~km}$, with concentrations of 1.5 to $1.7 \mathrm{ng} \mathrm{m}^{-3}$. Landis [2003] in a summer field program over Florida observed GEM to have a negative gradient with altitude.

[44] Over the eastern North Pacific in ITCT2K2 GEM was found to have a generally modest to strongly negative vertical gradient. Whole flight composite soundings show 

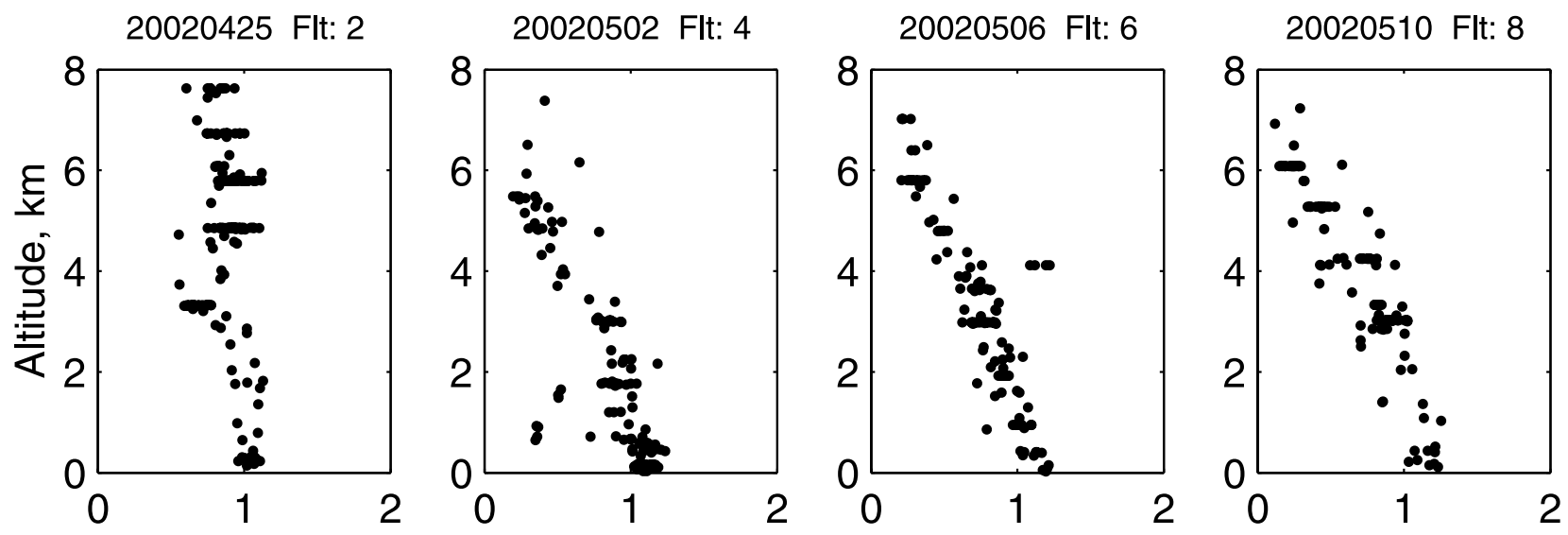

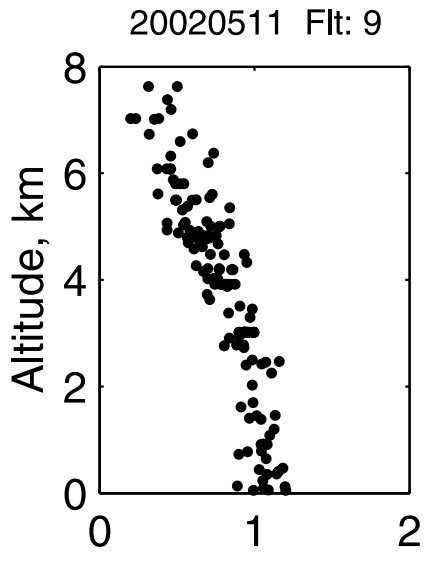

$\mathrm{Hg}, \mathrm{ng} \mathrm{m}^{-3}$

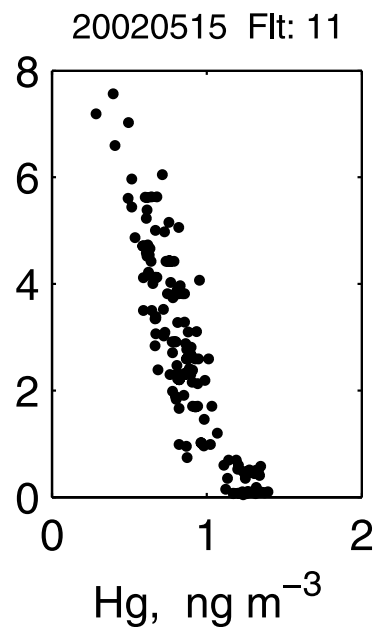

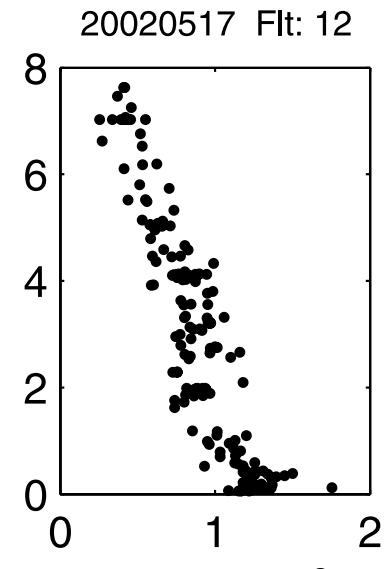

$\mathrm{Hg}, \mathrm{ng} \mathrm{m}^{-3}$

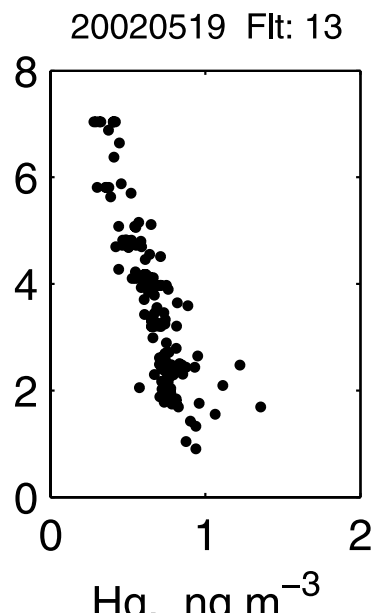

Figure 13. Flight by flight composite of GEM vertical distributions. Data from flights on 29 April, 5 May and 13 May 2002 were previously shown and not repeated here. GEM decreases slightly with altitude up to 3 to $4 \mathrm{~km}$ and then decreases at different rates to the highest sample altitudes. The change in GEM "lapse" rate at $3-4 \mathrm{~km}$ is paralleled in the potential temperature lapse rate ( $\theta$ is not shown here but was previously shown in figures for the flights on 29 April, 5 May, and 13 May).

three different and rather distinctive characteristics. These are presented in Figures 4, 7, 9 and 13. The principal characteristic is a significant, generally negative, gradient, with the GEM concentration falling as much as half an order of magnitude between sea level and $7-8 \mathrm{~km}$, as on the 2, 5 , 6, 10, and 11 May flights. The second characteristic can be seen in a few cases, such as 5 May (Figure 4), where GEM had little vertical gradient to $\sim 4 \mathrm{~km}$, when it became negative, but with one or more GEM-rich layers. In these cases the layer was also coincident with a strong $\mathrm{CO}$ increase (see both Figures 3 and 4). The third characteristic is seen on 25 and 29 April and 5 May (Figures 4 and 13), where below $2 \mathrm{~km}$, GEM showed little discernible vertical gradient. Above this mixed region, the gradient once again became negative.

[45] Surface sources, atmospheric stability, slow chemical oxidation in the troposphere and depleted GEM in UTLS impacted air may have all played a role in establishing the vertical gradient in GEM observed in ITCT2K2. GEM clearly has surface sources especially on land. The ocean can be a source regionally and may buffer GEM concentrations in the MBL. Photochemistry slowly removes GEM by reaction with radicals. The upper troposphere lower stratosphere was depleted in GEM and inferred stratospheric concentrations were $0 \mathrm{ng} \mathrm{m}^{-3}$. The flight plans selected for meteorologically stable conditions and suppress mixing and

Table 1. GEM Mixed Depth, Stratospheric-Influence, Plumes by Flight

\begin{tabular}{cccc}
\hline Date & $\begin{array}{c}\text { Stratospheric } \\
\text { Influence (UTLS) }\end{array}$ & \multicolumn{1}{c}{$\begin{array}{c}\text { GEM Mixed } \\
\text { Depth, m }\end{array}$} & $\begin{array}{c}\text { GEM + CO } \\
\text { Plumes }^{\mathrm{a}}\end{array}$ \\
\hline 25 Apr 2002 & & 3000 & $\mathrm{H}$ \\
29 Apr 2002 & $6-8 \mathrm{~km}$ & 5000 & $\mathrm{H}$ \\
2 May 2002 & & 2500 & $\cdots$ \\
5 May 2002 & & 4000 & $\mathrm{H}$ \\
6 May 2002 & $2-5 \mathrm{~km}$ & 5000 & $\mathrm{H}$ \\
10 May 2002 & & 3500 & $\mathrm{LH}$ \\
11 May 2002 & & 3500 & $\mathrm{H}$ \\
13 May 2002 & & 2500 & $\mathrm{LH}$ \\
15 May 2002 & & step at 1000, 4000 & $\mathrm{LH}$ \\
17 May 2002 & & step at 1000, 4000 & $\mathrm{LH}$ \\
19 May 2002 & & NA & LH \\
\hline
\end{tabular}

${ }^{\mathrm{a}} \mathrm{L}$, below $4 \mathrm{~km}$; H, above $4 \mathrm{~km}$. 
Table 2. Mercury, Ozone, Carbon Monoxide, and Water Vapor ${ }^{\mathrm{a}}$

\begin{tabular}{|c|c|c|c|c|c|c|c|c|}
\hline Flight & Samples & Latitude, ${ }^{\circ} \mathrm{N}$ & Longitude, ${ }^{\circ} \mathrm{E}$ & $\mathrm{Hg}, \mathrm{ng} \mathrm{m}^{-3}$ & $\mathrm{CO}, \mathrm{ppb}$ & $\mathrm{O}_{3}, \mathrm{ppb}$ & $\mathrm{H}_{2} \mathrm{O}, \mathrm{hPa}$ & Location \\
\hline \multicolumn{9}{|c|}{ More Than $100 \mathrm{~km}$ From Coastline } \\
\hline 20020425 & 1 & 35.37 & -126.97 & 1 & 123 & 37 & 11.99 & $\sim 500 \mathrm{~km} \mathrm{~W}$ Morro Bay, CA \\
\hline 20020425 & 3 & 36.96 & -123.04 & 1.1 & 138 & 40 & 10.85 & $\sim 100 \mathrm{~km} \mathrm{~W}$ Monterey, CA \\
\hline 20020429 & 9 & 36.99 & -127.17 & 1.1 & 150 & 46 & 8.86 & $\sim 400 \mathrm{~km} \mathrm{~W}$ of Monterey, CA \\
\hline 20020429 & 1 & 37.00 & -122.76 & 1.1 & 148 & 50 & 8.20 & $\sim 100 \mathrm{~km}$ W Monterey, A \\
\hline 20020502 & 32 & 40.55 & -124.85 & 1.1 & 131 & 41 & 9.76 & $\sim 100 \mathrm{~km} \mathrm{~W}$ of Trinidad Head, CA \\
\hline 20020505 & 1 & 41.04 & -124.89 & 1.1 & 119 & 38 & 9.67 & $\sim 100 \mathrm{~km} \mathrm{~W}$ of Trinidad Head, CA \\
\hline 20020505 & 1 & 36.85 & -122.82 & 1.1 & 122 & 42 & 11.10 & $\sim 100 \mathrm{~km} \mathrm{~W}$ Monterey, CA \\
\hline 20020510 & 2 & 41.02 & -127.20 & 1.1 & 126 & 38 & 7.94 & $\sim 300 \mathrm{~km} \mathrm{~W}$ of Trinidad Head, CA \\
\hline 20020511 & 2 & 47.75 & -124.92 & 1.1 & 123 & 43 & 5.37 & $\sim 100 \mathrm{~km} \mathrm{~W}$ of Aberdeen, WA \\
\hline 20020515 & 5 & 32.31 & -128.54 & 1.2 & 129 & 48 & 10.85 & $\sim 1100 \mathrm{~km} \mathrm{~W}$ San Diego, CA \\
\hline 20020515 & 6 & 37.42 & -126.67 & 1.2 & 132 & 43 & 9.76 & $\sim 400 \mathrm{~km} \mathrm{~W}$ of Half Moon Bay, CA \\
\hline 20020517 & 7 & 36.40 & -122.56 & 1.3 & 118 & 36 & 11.82 & $\sim 100 \mathrm{~km} \mathrm{~W}$ Monterey, CA \\
\hline 20020517 & 3 & 35.14 & -124.20 & 1.2 & 112 & 34 & 12.31 & $\sim 300 \mathrm{~km}$ W Morro Bay, CA \\
\hline 20020517 & 7 & 30.73 & -129.32 & 1.2 & 106 & 27 & 13.37 & $\sim 1900 \mathrm{~km} \mathrm{~W}$ of Baja, Mexico \\
\hline 20020517 & 6 & 34.67 & -125.27 & 1.3 & 107 & 32 & 13.41 & $\sim 500 \mathrm{~km} \mathrm{~W}$ of Lompoc, CA \\
\hline Mean & & & & 1.2 & 125 & 40 & 10.35 & \\
\hline Std-Dev & & & & 0.1 & 13 & 6 & 2.19 & \\
\hline \multicolumn{9}{|c|}{ Within $100 \mathrm{~km}$ of Coastline } \\
\hline 20020502 & 3 & 41.06 & -124.30 & 1.1 & 140 & 41 & 10.10 & near Trinidad Head, CA \\
\hline 20020505 & 1 & 36.59 & -121.82 & 1.3 & 142 & 43 & 9.46 & near Monterey, CA \\
\hline 20020506 & 2 & 40.93 & -124.18 & 1.2 & 134 & 43 & 7.82 & near Trinidad Head, CA \\
\hline 20020506 & 1 & 36.74 & -121.96 & 1.2 & 131 & 43 & 9.29 & near Monterey, CA \\
\hline 20020510 & 1 & 40.99 & -124.18 & 1.2 & 128 & 41 & 8.11 & near Trinidad Head, CA \\
\hline 20020510 & 1 & 36.77 & -121.96 & 1.2 & 121 & 42 & 8.93 & near Monterey, CA \\
\hline 20020511 & 4 & 40.95 & -124.22 & 1 & 147 & 49 & 6.72 & near Trinidad Head, CA \\
\hline 20020511 & 1 & 36.73 & -122.11 & 1.2 & 132 & 48 & 6.41 & near Monterey, CA \\
\hline 20020513 & 2 & 36.80 & -121.99 & 1.1 & 135 & 52 & 8.44 & near Monterey, CA \\
\hline 20020513 & 2 & 33.52 & -118.41 & 1.4 & 224 & 65 & 10.00 & near Los Angeles, CA \\
\hline 20020513 & 3 & 33.49 & -118.27 & 1.2 & 150 & 68 & 10.97 & near Los Angeles, CA \\
\hline 20020515 & 6 & 41.05 & -124.23 & 1.3 & 135 & 42 & 9.10 & near Trinidad Head, CA \\
\hline 20020515 & 1 & 36.70 & -122.06 & 1.3 & 132 & 49 & 10.64 & near Monterey, CA \\
\hline 20020517 & 4 & 36.87 & -122.03 & 1.4 & 136 & 41 & 11.14 & near Monterey, CA \\
\hline Mean & & & & 1.2 & 142 & 48 & 9.08 & \\
\hline Std-Dev & & & & 0.1 & 25 & 9 & 1.47 & \\
\hline
\end{tabular}

${ }^{a}$ Sampled from nearest surface over the Pacific. Pressure or altitude criteria: $\mathrm{P}=1010-985 \mathrm{hPa}$ or $\mathrm{Z}=$ surface $-210 \mathrm{~m}$.

the replenishment of GEM to the middle and upper troposphere except in the cases where distant convection has lofted plumes of GEM. These factors: sources on the surface, sinks at the tropopause and suppressed mixing, would all favor a negative gradient in GEM.
[46] In summary, the limited number of GEM soundings here and in the cited literature need be considered in conflict, as their differences in altitude structure may be entirely due to differences in the time since the last overturning of the troposphere.

Table 3. GEM Comparison With Other Pacific Observations

\begin{tabular}{|c|c|c|c|c|}
\hline Site & Period & Mean (Median) & Range & Reference \\
\hline Coastal East Pacific, $<250 \mathrm{~m}$ & 27 Apr to 19 May 2002 & $1.2(1.2)$ & $1.0-1.4$ & this work \\
\hline Okinawa, $0 \mathrm{~km}$ & 1 Jan to 31 May 2005 & $2.0(2.0)$ & $1.4-4.7$ & Jaffe et al. [2003] \\
\hline Mid N. Pacific, $0 \mathrm{~km}$ & & $1.7(\mathrm{na})$ & & Lamborg et al. [2002a, 2002b] \\
\hline Pacific, $35^{\circ} \mathrm{S}$ to $80^{\circ} \mathrm{N}$ & $1980-1986$ & $\sim 1.6$ & $0.8-2.3$ & Fitzgerald [1995] \\
\hline ACE-Asia, $0-1 \mathrm{~km}$ & spring 2000 & $\mathrm{na}(2.0)$ & $1.7-2.3$ & Friedli et al. [2004] \\
\hline $\begin{array}{l}\text { Coastal East Pacific, } \\
2.3-3.3 \mathrm{~km} \text { north of } 40^{\circ} \mathrm{N}\end{array}$ & & $0.9 \sim 0.1$ & & this work \\
\hline Cheeka Peak, WA, 1 km & spring & $1.5(\mathrm{na})$ & & Weiss-Penzias et al. [2003] \\
\hline Cheeka Peak, WA, 1 km & summer & $1.6(\mathrm{na})$ & & Weiss-Penzias et al. [2003] \\
\hline Cheeka Peak, WA, $1 \mathrm{~km}$ & fall & 1.5 & & Weiss-Penzias et al. [2003] \\
\hline Cheeka Peak, WA, 1 km & winter & 1.5 & & Weiss-Penzias et al. [2003] \\
\hline Washington coast, $0-3 \mathrm{~km}$ & spring 2006 & 1.4(na) & $1.1-2.0$ & authors unpublished work \\
\hline Mt Bachelor, OR, 2.8 km & 15 Apr to 27 May 2004 & $1.8(1.8)$ & $1.5-2.5$ & Weiss-Penzias et al. [2006] \\
\hline Mt Bachelor, OR, $2.8 \mathrm{~km}$ & 15 Apr to 27 May 2005 & $1.7(1.7)$ & $1.2-2.1$ & $\begin{array}{l}\text { D. Jaffe (personal communication, } \\
\text { 2006) }\end{array}$ \\
\hline Canada, $0-7 \mathrm{~km}$ & winter & 1.1 & $0.4-1.7$ & Banic et al. [2003] \\
\hline Ontario, $0-7 \mathrm{~km}$ & summer & 1.7 & $1.0-2.4$ & Banic et al. [2003] \\
\hline Southeast Canada, $0-7 \mathrm{~km}$ & spring & 1.5 & $1.0-2.5$ & Banic et al. [2003] \\
\hline
\end{tabular}




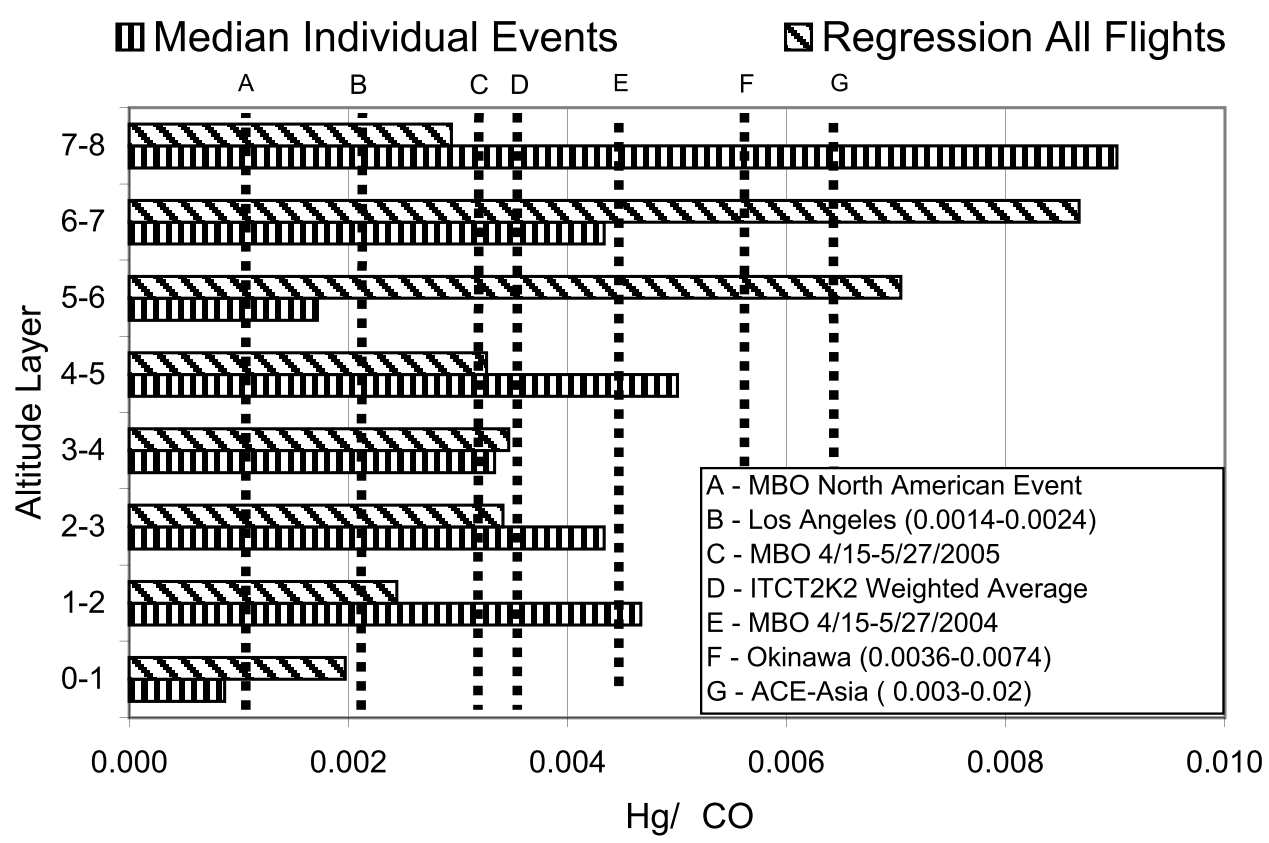

Figure 14. Comparison of the change in GEM with the corresponding change in CO. Vertical striped bars show the median of hand pick events within a $1 \mathrm{~km}$ altitude bin for all flights (typically only $3-6$ events are seen in an altitude bin). Diagonal striped bars show the regression slope for all data within a $1 \mathrm{~km}$ altitude bin for all flights. Dashed lines indicate nominal ratios identified in specific ITCT2K2 events (A and B) and from the literature (C, E, F [Jaffe et al., 2005], and G [Friedli et al., 2004]). The legend provides ranges observed. The UTLS event is not shown.

\subsection{UTLS GEM}

[47] The stratospherically influenced air samples were a mixture of upper tropospheric and lower stratospheric air, UTLS. In the upper troposphere, concentrations of GEM were $0.3-0.5 \mathrm{ng} / \mathrm{m}^{3}$. From the $\mathrm{O}_{3}$-GEM regression analysis GEM was expected to be zero in UTLS air containing $\sim 350 \mathrm{ppb} \mathrm{O}_{3}$. The chemical mechanism of GEM loss in the UTLS is unknown. Holmes et al. [2006] have shown through model simulations that $\mathrm{Br}$ chemistry will deplete GEM in the UTLS.

[48] The quantitative conversion of GEM to, most likely, particulate mercury through RGM is supported by the observations of Murphy et al. [1998, 2003] and Ivlev et al. [1989]. They observed anomalous aerosol layers containing $\mathrm{pHg}$ in the UTLS region near the tropopause. The mechanism of stratospheric depletion and $\mathrm{pHg}$ production is uncertain.

\subsection{CO to GEM Ratios}

[49] The GEM to CO correlation or $\triangle \mathrm{GEM}: \Delta \mathrm{CO}$ was used to identify Asian air masses impacting North America [e.g., Jaffe et al., 2005]. The key values were an Asian ratio observed in two plumes at Mt. Batchelor Observatory, $\sim 0.0045 \mathrm{ng} \mathrm{m}^{-3} \mathrm{ppb}^{-1}$ and a corresponding value on Okinawa, $\sim 0.0056 \mathrm{ng} \mathrm{m}^{-3} \mathrm{ppb}^{-1}$. In ITCT2K2 there was a wide span in visually deduced $\triangle \mathrm{GEM}: \Delta \mathrm{CO}$ ratios ranging from 0.0000 to 0.035 . The 5 May plume study yield values of $0.002,0.024$ and $0.035 \mathrm{ng} \mathrm{m}^{-3} \mathrm{ppb}^{-1}$. The Los Angeles basin $\Delta \mathrm{GEM} / \Delta \mathrm{CO}$ ratio was $0.002 \mathrm{ng} \mathrm{m}^{-3} \mathrm{ppb}^{-1}$. The visual GEM event selection process failed to have a single occurrence of a positive GEM event without a zero or positive $\mathrm{CO}$ event, although there were a couple of $\mathrm{CO}$ events without a concurrent increase in GEM. Figure 14 shows the median event based $\triangle \mathrm{GEM}$ to $\triangle \mathrm{CO}$ ratio for each $1 \mathrm{~km}$ interval (vertically hatched bars). Each level had at least 3 events. Also plotted on Figure 14 is the $\triangle \mathrm{GEM}: \triangle \mathrm{CO}$ slope determined from linear regression applied to CO-GEM data for each layer (diagonally hatched bar). Last, the heavy vertical dotted lines of Figure 14 indicate summary ratios from this work and the literature. A cursory reexamination of the ACE-Asia data for $\mathrm{CO}$ and GEM showed $\Delta \mathrm{GEM} / \Delta \mathrm{CO}$ ranged from $<0.001$ to $>0.02$ $\mathrm{ng} \mathrm{m}^{-3} \mathrm{ppb}^{-1}$ in that program. In ITCT2K2 there is a trend for the $\triangle \mathrm{GEM}: \triangle \mathrm{CO}$ ratio to increase with altitude. The vertical lines also suggest an increase in $\triangle \mathrm{GEM}: \triangle \mathrm{CO}$ ratio from North American local to Asian transported plumes. The trend with height may then reflect a shift in GEM-CO source regions from western North American sources at low altitude to Asian or further upstream sources at high altitude.

\subsection{GEM Lifetime Estimate}

[50] The current estimated GEM residence time is $\sim 1$ year, where the residence time of GEM is defined by dividing the atmospheric burden by either the source rate or sink rate of GEM. A 1 year residence time was considered to be inconsistent with a pronounced negative vertical gradient observed in GEM during ITCT2K2. The GEM mean to variance ratio of all quantifiable samples was comparable to that observed in $\mathrm{CO}$ which has a photochemical lifetime on the order of 100 days. Such comparisons between a compound with unknown lifetime and compounds with known 
Table 4. Calculated Tropospheric Residence Time for GEM by Flight Date

\begin{tabular}{lcccc}
\hline \multicolumn{1}{c}{ Date } & Mean GEM & Std.Dev. & RSD & $\begin{array}{c}\text { Residence } \\
\text { Time, days }\end{array}$ \\
\hline 25 Apr 2002 & 0.69 & 0.34 & 0.47 & 102.9 \\
29 Apr 2002 & 0.93 & 0.35 & 0.38 & 134.6 \\
2 May 2002 & 0.67 & 0.37 & 0.56 & 91.8 \\
5 May 2002 & 0.63 & 0.62 & 0.99 & 51.6 \\
6 May 2002 & 0.58 & 0.39 & 0.67 & 75.8 \\
10 May 2002 & 0.54 & 0.39 & 0.72 & 71.3 \\
13 May 2002 & 0.56 & 0.31 & 0.55 & 93.6 \\
15 May 2002 & 0.82 & 0.44 & 0.53 & 95.9 \\
17 May 2002 & 0.66 & 0.31 & 0.47 & 109.7 \\
19 May 2002 & 0.73 & 0.32 & 0.44 & 115.2 \\
Average & 0.68 & 0.34 & 0.57 & 94.2 \\
\hline
\end{tabular}

lifetimes is a classic method to infer the lifetime or characteristic timescale of the unknown compound [Seinfeld and Pandis, 1998].

[51] Junge [1974] reasoned that the residence time of trace gases should be inversely proportional to their variability and reasoned on theoretical grounds the residence time, $\Gamma$ in years, was given by:

$$
\Gamma(\text { years }) \equiv(0.14)(\text { Mean concentration }) /(\text { Std Deviation })
$$

[52] He emphasized this approach was quantitatively valid (1) only "if the distribution of sources and sinks are similar" and (2) the trace gas of interest should be nearly at planetary steady state.

[53] GEM substantially meets these requirements. In ITCT2K2 cross Pacific transport at least partially homogenized the impact of strong Asian sources. In 11 flights directed to the study of intercontinental transport only two contained well defined plumes of GEM and other tracer compounds and these were sampled for a small fraction of the total sampling times. There were numerous small GEM events with highly variable $\triangle \mathrm{GEM}: \triangle \mathrm{CO}$ ratios which suggested a blending of source regions. The putative chemical sinks of GEM: $\mathrm{O}_{3}, \mathrm{HO}, \mathrm{NO}_{3}$, halogen and halogen monoxide radicals, were secondary oxidants whose natural and anthropogenic precursors shared in large part the same geographic source regions as GEM. Prior long-term studies have shown atmospheric concentrations of GEM are without annual trends, except after major volcanic eruptions [e.g., Fitzgerald et al., 1991; Ebinghaus et al., 2002; WeissPenzias et al., 2006] and suggested GEM was in global steady state.

[54] The ITCT2K2 data set was used to determine $\Gamma$ for each flight using (equation (1)). These residence times are given in Table 4 . The estimated residence times are seen to span $\sim 50$ to $\sim 130$ days and to average $\sim 94$ days. The GEM residence time estimate for the 5 May flight was 52 days, which was decidedly shorter than the estimates for the other flights. This was the day when LRT of an Asian air mass was observed at many levels and which had the highest GEM standard deviation. It is conceivable this flight was subject to strong source variations and did not meet the 1 st criteria. In contrast, the 2 May flight did not have any identifiable plumes at any level (Table 1) and its residence time estimate, 92 days, was very near the mean value estimated above. For comparison, Fitzgerald [1986] using measurements made on a small Pacific island derived a similar residence time of 100 days using the Junge approach. Weiss-Penzias et al. [2003], reported a somewhat longer Junge residence time of 7 months in the summer at the Cheeka Peak Observatory, WA.

[55] In review, it was pointed out that one last caveat is in order. The Junge analysis above assumed the ITCT2K2 samples were meteorologically unbiased and the samples were collected over sufficient spatial-temporal scales for ergodicity to apply.

\subsection{Study Implications}

[56] The observed vertical gradient in GEM concentration if extrapolated over the world's oceans, would lead to a onethird reduction in the estimated tropospheric GEM reservoir to 4000 tonnes. A reduction of the atmospheric burden leads to a concurrent decrease in residence time by one third assuming sources and sinks remain constant.

[57] Separately, a reduction of GEM's tropospheric residence time by about two thirds to the 100 day estimate made here required a reassessment of the sum of the source terms. Assuming current anthropogenic GEM estimates were correct at 3000 tonnes/yr, then the shorter residence time and atmospheric burden implied the estimated natural sources of GEM must increase by nearly a factor of 3 to about 9,000 tonnes $\mathrm{yr}^{-1}$. Conversely, assuming the natural sources were correct and total 3000 tonnes then a threefold increase in anthropogenic sources is needed. Either way the implied changes to the GEM budget would be large.

[58] The complexity revealed in the ITCT2K2 GEM measurements underscores the need for additional tropospheric observations of GEM. They were in considerable contrast with the more continental perspective provided by surface observation networks and earlier airborne observations.

[59] The budgetary points above were necessarily speculative and driven by the present study's limited data set. They need to be confirmed or refuted directly by observations in the stratosphere, over the southern oceans and by more work in the Northern Hemisphere's troposphere.

\section{Conclusions}

[60] GEM was observed over the eastern North Pacific in spring 2002 as part of the ITCT2K2 mission. The measurements were at the low end of the range of prior observations. GEM was found to be distributed in distinct layers and often together with chemical signatures of distant anthropogenic and natural sources. GEM concentrations in these few plumes, when contrasted with ACE-Asia's observations near the Asian coastline, appeared to be nearly conserved during trans Pacific transport. GEM was generally correlated with $\mathrm{CO}$ and $\mathrm{O}_{3}$. Visually identified individual plume events showed variable changes in GEM relative to changes in $\mathrm{CO}$. The highest concentrations of GEM were associated with combustion, high $\mathrm{CO}$, and intermediate values of $\mathrm{O}_{3}$ (pollution and biomass fire). The lowest GEM concentrations were associated with UTLS impacted air high in $\mathrm{O}_{3}$, low in $\mathrm{CO}$ and very low in GEM. GEM was also observed to be low in air with low propane to ethane ratios indicative of highly processed (well aged) continental 
air masses. The upper troposphere lower stratospheric air depletion in GEM suggested a heretofore unrecognized GEM sink. Also, the GEM-O ${ }_{3}$ trend in the UTLS provided an additional quantitative measure of stratosphere-troposphere mixing. The combination of GEM's observed variability, negative vertical gradient, and Junge residence time analysis suggested a GEM residence time nearer 100 days than the current value of 1 year.

[61] Acknowledgments. The Electric Power Research Institute under contract P2044/C896, NOAA, and the National Center for Atmospheric Research provided funding for this project, which is operated by the University Corporation for Atmospheric Research with the sponsorship of the National Science Foundation. We thank Joost de Gouw for sharing his data and for running our instrument when there was not room for us. We particularly thank Gerd Hubler for his assistance in installing our instrument in the WP-3, Stephen Donnelly for advice and assistance with pressure control applications, Daniel Jaffe for sharing his GEM data from Mt. Batchelor Observatory, Ryan Prescott for data analysis, Hayden Radke for assistance with the figures, and the pilots. Special thanks to the NOAA staff who have kept the ITCT2K2 achieves alive and to the crew of the WP-3 for a flight program executed to perfection.

\section{References}

Abramovsky, B. P., Y. A. Anokhin, V. A. Ionov, I. M. Nazarov, and A. H. Ostromogilsky (1977), Estimation of global mercury balance and critical limits of mercury emission to the atmosphere, in Atmospheric Pollution as an Ecological Factor, Issue of Inst. of Appl. Geophys., vol. 39, pp. 419, Gidrometeoizdat, Moscow.

Banic, C. M., S. T. Beauchamp, R. J. Tordon, W. H. Schroeder, A. Steffen, K. A. Anlauf, and H. K. T. Wong (2003), Vertical distribution of gaseous elemental mercury in Canada, J. Geophys. Res., 108(D9), 4264, doi:10.1029/2002JD002116.

Bergan, T., and H. Rodhe (2001), Oxidation of elemental mercury in the atmosphere; Constraints imposed by global scale modeling, J Atmos. Chem., 40, 191-212.

Cooper, O., et al. (2004), On the life cycle of a stratospheric intrusion and its dispersion into polluted warm conveyor belts, J. Geophys. Res., 109, D23S09, doi:10.1029/2003JD004006.

de Gouw, J. A., et al. (2004), Chemical composition of air masses transported from Asia to the U.S. West Coast during ITCT 2K2: Fossil fuel combustion versus biomass-burning signatures, J. Geophys. Res., 109, D23S20, doi:10.1029/2003JD004202.

Ebinghaus, R., and F. Slemr (2000), Aircraft measurements of atmospheric mercury over southern Germany, Atmos. Environ., 34, 895-903.

Ebinghaus, R., H. H. Kock, A. M. Coggins, T. G. Spain, S. G. Jennings, and C. Temme (2002), Long-term measurements of atmospheric mercury at Mace Head, Irish west coast, between 1995 and 2001, Atmos. Environ., $36,5267-5276$

Fitzgerald, W. F. (1986), Cycling of mercury between the atmosphere and oceans, in The Role of Air-Sea Exchange in Geochemical Cycling, edited by P. Buat-Ménard, pp. 363-408, Springer, New York.

Fitzgerald, W. F. (1995), Is mercury increasing in the atmosphere? The need for an atmospheric mercury network (AMNET), Water Air Soil Pollut., $80,245-254$.

Fitzgerald, W. F., R. P. Mason, and G. M. Vandal (1991), Atmospheric cycling and air-water exchange of mercury over mid-continental lacustrine regions, Water Soil Air Pollut., 56, 745-767.

Friedli, H. R., L. F. Radke, and J. Y. Lu (2001), Mercury in smoke from biomass fires, Geophys. Res. Lett., 28(17), 3223-3226.

Friedli, H. R., L. F. Radke, J. Y. Lu, C. M. Banic, W. R. Leaitch, and J. I. MacPherson (2003a), Mercury emissions from burning of biomass from temperate North American forests: Laboratory and airborne measurements, Atmos. Environ., 37, 253-2672.

Friedli, H. R., L. F. Radke, R. Prescott, P. V. Hobbs, and P. Sinha (2003b), Mercury emissions from the August 2001 wildfires in Washington State and an agricultural waste fire in Oregon and atmospheric mercury budget estimates, Global Biogeochem. Cycles, 17(2), 1039, doi:10.1029/ 2002GB001972.

Friedli, H. R., L. F. Radke, R. Prescott, P. Li, J.-H. Woo, and G. Carmichael (2004), Mercury in the atmosphere around Japan/China as observed during the 2001 ACE-Asia field campaign: Measurements, distributions, sources and implications, J. Geophys. Res., 109, D19S25, doi:10.1029/ 2003JD004244.

Gormley, P. G., and M. Kennedy (1949), Diffusion from a stream flowing through a cylindrical tube, Proc. Irish Acad., 52A, 163-170.
Gregory, G. L., J. T. Merrill, M. C. Shipham, D. R. Blake, G. W. Sachse, and H. B. Singh (1997), Chemical characteristics of tropospheric air over the Pacific Ocean as measured during PEM-West B: Relationship to Asian outflow and trajectory history, J. Geophys. Res., 102, 28,27528,285 .

Hall, B. (1995), The gas-phase oxidation of elemental mercury by ozone, Water Soil Air Pollut., 80, 301-315.

Hedgecock, I. M., and N. Pirrone (2004), Chasing quicksilver: Modeling the atmospheric lifetime of $\mathrm{HgO}(\mathrm{g})$ in the marine boundary layer at various latitudes, Environ. Sci. Technol., 38, 69-76.

Holmes, C. D., D. J. Jacob, and X. Yang (2006), Global lifetime of elemental mercury against oxidation by atomic bromine in the free troposphere, Geophys. Res. Lett., 33, L20808, doi:10.1029/2006GL027176.

Ivlev, L. S., V. M. Shukov, V. T. Kudryashov, and S. N. Pogorsky (1989), Study of the microstructure and chemistry of the stratospheric aerosol, Izv. Acad. Sci. USSR Phys. Atmos. Oceans, 25(3), 293-300.

Jaffe, D., E. Prestbo, P. Swartzendruber, P. Weiss-Penzias, S. Kato, A. Takami, S. Hatakeyama, and Y. Kajii (2005), Export of atmospheric mercury from Asia, Atmos. Environ., 39, 3029-3038, doi:10.1016/j. atmosenv.2005.01.30.

Jaffe, D., I. McKendry, T. Anderson, and H. Price (2003), Six "new" episodes of trans-Pacific transport of air pollutants, Atmos. Environ., $37,391-404$.

Junge, C. E. (1974), Residence time and variability of tropospheric trace gases, Tellus, Ser. B, 31, 477-488.

Kvietkus, K. (2003), Investigation of the gaseous and particulate mercury concentrations along horizontal and vertical profiles in the tower troposphere, in Proceedings of the 10th World Clean Air Congress, vol. 2, Atmospheric Pollution, edited by P. Anttiba, J. Kämäri, and M. Jolvanen, pp. 284-287, Finn. Air Pollut. Prev. Soc., Helsinki.

Lamborg, C. H., W. F. Fitzgerald, W. H. Damman, J. M. Benoit, P. H. Balcom, and D. R. Engstrom (2002a), Modern and historic atmospheric mercury fluxes in both hemispheres: Global and regional mercury cycling implications, Global Biogeochem. Cycles, 16(4), 1104, doi:10.1029/ 2001 GB001847.

Lamborg, C. H., W. F. Fitzgerald, J. O’Donnell, and T. Torgersen (2002b), A non-steady-state compartmental model of global-scale mercury biogeochemistry with interhemispheric atmospheric gradients, Geochim. Cosmochim. Acta, 66, 1105-1118.

Landis, M. S. (2003), NERL atmospheric mercury monitoring: Knowledge and future needs, paper presented at Long Range Transport Workshop, Natl. Exposure Risk Lab., U.S. Environ. Prot. Agency, Research Triangle Park, N. C., 16 Sept.

Lindberg, S. E., and W. J. Stratton (1998), Atmospheric mercury speciation: Concentrations and behavior of reactive gaseous mercury in ambient air, Environ. Sci. Technol., 32, 49-57.

Lindberg, S. E., S. Brooks, C.-J. Lin, K. J. Scott, M. S. Landis, R. K. Stevens, M. Goodsite, and A. Richter (2002a), Dynamic oxidation of gaseous mercury in the Arctic troposphere at polar sunrise, Environ. Sci. Technol., 36, 1245-1256.

Lindberg, S. E., W. Dong, and T. Meyers (2002b), Transpiration of gaseous elemental mercury through vegetation in a subtropical wetland in Florida, Atmos. Environ., 36, 5207-5219.

Mason, R. P., and G.-R. Sheu (2002), Role of the ocean in the global mercury cycle, Global Biogeochem. Cycles, 16(4), 1093, doi:10.1029/ $2001 \mathrm{~GB} 001440$.

Mason, R. P., W. F. Fitzgerald, and F. M. M. Morel (1994), The biogeochemical cycling of elemental mercury: Anthropogenic influences, Geochim. Cosmochim. Acta, 58, 3191-3198.

Mason, R. P., N. M. Lawson, and G.-R. Sheu (2001), Mercury in the Atlantic Ocean: Factors controlling air-sea exchange of mercury and its distribution in the upper waters, Deep Sea Res., Part II, 48, 2829-2853.

Mason, R. P., N. M. Lawson, and G.-R. Sheu (2002), The urban atmosphere: An important source of trace metals to nearby waters?, in Chemicals in the Environment: Fate, Impacts, and Remediation, ACS Symp. Ser, vol. 806, edited by R. L. Lipnick et al., pp. 203-222, Am. Chem. Soc., New York.

McKeen, S. A., S. C. Liu, E.-Y. Hsie, X. Lin, J. D. Bradshaw, S. Smyth, G. L. Gregory, and D. R. Blake (1996), Hydrocarbons ratios during PEMWest A: a model perspective, J. Geophys. Res., 101, 2087-2109.

Murphy, D. M., D. S. Thomson, and M. J. Mahoney (1998), In situ measurements of organics, meteoritic material, mercury, and other elements in aerosols at 5 to 19 kilometers, Science, 282, 1664-1669.

Murphy, D. M., D. S. Thomson, and P. J. Sheridan (2003), Observations of mercury-containing aerosols in the tropopause region, J. Phys. IV, 107, 907, doi:10.1051/jp4: 20030445.

Nowak, J. B., et al. (2004), Gas-phase chemical characteristics of Asian emission plumes observed during ITCT $2 \mathrm{~K} 2$ over the eastern North Pacific Ocean, J. Geophys. Res., 109, D23S19, doi:10.1029/2003JD004488. 
Nriagu, J., and C. Becker (2003), Volcanic emissions of mercury to the atmosphere: Global and regional inventories, Sci. Total Environ., 304, 3-12.

Pal, B., and P. A. Ariya (2004), Gas-phase HO-initiated reactions of elemental mercury: Kinetics, product studies, and atmospheric implications, Environ. Sci. Technol., 38(21), 5555-5566.

Parrish, D. D., Y. Kondo, O. R. Cooper, C. A. Brock, D. A. Jaffe, M. Trainer, T. Ogawa, G. Hübler, and F. C. Fehsenfeld (2004), Intercontinental Transport and Chemical Transformation 2002 (ITCT 2K2) and Pacific Exploration of Asian Continental Emission (PEACE) experiments: An overview of the 2002 winter and spring intensives, J. Geophys. Res., 109, D23S01, doi:10.1029/2004JD004980

Pilson, M. E. Q. (1998), An Introduction to the Chemistry of the Sea, 395 pp., Prentice-Hall, Upper Saddle River, N. J.

Rasmussen, P. E. (1994), Current methods of estimating atmospheric mercury fluxes in remote areas, Environ. Sci. Technol., 28, 2233-2234.

Richardson, M. G. (2001), Critical review on natural global and regional emissions of six trace metals to the atmosphere, final report, pp. 17-23, Risklogic Sci. Services, Inc., Ottawa, Ont., Canada, July.

Schroeder, W. H., and J. Munthe (1998), Atmospheric mercury: An overview, Atmos Environ., 32, 809-822.

Schroeder, W. H., G. Yarwood, and H. Niki (1991), Transformation processes involving mercury species in the atmosphere: Results from a literature survey, Water Air Soil Pollut., 56, 653-666.

Seinfeld, J. H., and S. N. Pandis (1998), Atmospheric Chemistry and Physics, John Wiley, New York.
Selin, N. E., D. J. Jacob, R. J. Park, R. M. Yantosca, S. Strode, L. Jaeglé, and D. Jaffe (2007), Chemical cycling and deposition of atmospheric mercury: Global constraints from observations, J. Geophys. Res., 112 D02308, doi:10.1029/2006JD007450.

Takizawa, Y. (1979), Epidemiology of mercury poisoning, in The Biochemistry of Mercury in the Environment, edited by J. O. Nriagu, pp. $325-$ 366, Elsevier, New York.

Temme, C., F. Slemr, R. Ebinghaus, and J. W. Einax (2003), Distribution of mercury over the Atlantic Ocean in 1996 and 1999-2001, Atmos. Environ., 37, 1889-1897.

Weiss-Penzias, P., D. A. Jaffe, A. McClintick, E. M. Prestbo, and M. S. Landis (2003), Gaseous elemental mercury in the marine boundary layer: Evidence for rapid removal in anthropogenic pollution, Environ. Sci. Technol., 37, 3755-3763

Weiss-Penzias, P., D. A. Jaffe, P. Swartzendruber, J. B. Dennison, D. Chand, W. Hafner, and E. Prestbo (2006), Observations of Asian air pollution in the free troposphere at Mount Bachelor Observatory during the spring of 2004, J. Geophys. Res., 111, D10304, doi:10.1029/2005JD006522.

H. R. Friedli and L. F. Radke, Advanced Study Program, National Center for Atmospheric Research, Boulder, CO 80307, USA. (radke@ucar.edu)

B. G. Heikes, Graduate School of Oceanography, University of Rhode Island, Narragansett, RI 02882, USA. 